\title{
Cleopatra VII Filópator y la legitimación del poder ptolemaico ${ }^{1}$
}

\section{Cleopatra VII Philopator and the legitimation of Ptolemaic power}

\author{
Ma Amparo ARROYO DE LA FUENTE \\ Doctora. Universidad Complutense de Madrid \\ amparoarroyo@movistar.es
}

Recibido: 30/10/2013

Aceptado: 26/11/2013

Resumen: Las diversas fórmulas de legitimación del poder empleadas durante la época ptolemaica se caracterizaron, desde los inicios mismos de la dinastía, por una doble concepción: aquellas imágenes destinadas a la población egipcia liberada de la dominación persa y, por otra parte, las dirigidas a los pobladores griegos de las ciudades de nueva planta, particularmente, de Alejandría. La legitimación de corte helenístico se asentaría sobre la imagen misma de Alejandro; por el contrario, la consolidación del poder de los ptolomeos entre la población autóctona se construyó de acuerdo con las tradicionales fórmulas de legitimación del poder faraónico. En el caso de la última de las mandatarias ptolemaicas, Cleopatra VII Filópator, esta particular dicotomía iconográfica se enriqueció con una nueva visión de la reina, provocada por la necesidad de elaborar y difundir su imagen, no solo en el interior del país, sino también en el entorno del Imperio Romano.

Palabras Clave: Alejandro Magno, Cleopatra VII Filópator, Dinastía ptolemaica, Iconografía del poder.

\begin{abstract}
The various forms of legitimation of power used during the Ptolemaic era were characterized, from the very beginning of the dynasty, by a double conception: on one hand, those images intended for the Egyptian population freed from Persian domination and, on the other hand, those aimed at the Greek settlers from the recently-founded cities, particularly, Alexandria. The legitimation of Hellenistic type would be based on the image of Alexander the Great; on the contrary, the consolidation of Ptolemaic power among the native population was built according to the traditional formulas of power legitimation distinctive of the Pharaonic era. In the case of the last of the Ptolemaic rulers, Cleopatra VII Philopator, this particular iconographic dichotomy was enriched with a new vision of the queen, caused by the need to elaborate and spread her image, not only within the country, but in the Roman Empire as well.
\end{abstract}

Key Words: Alexander the Great, Cleopatra VII Philopator, Ptolemaic Dynasty, Iconography of power.

Sumario: 1. La legitimación ptolemaica del poder. 1.1. Alejandro Magno y la iconografía del poder. 1.2. Los sucesores de Alejandro y la consolidación del poder ptolemaico. 2. Cleopatra VII Filópator. 2.1. Numismática e imágenes helenísticas. 2.2. Reina de Egipto. 2.3. Cleopatra en Roma. 3. Conclusiones. Fuentes y Bibliografía.

$$
* * * * *
$$

\footnotetext{
${ }^{1}$ El presente artículo es fruto de la conferencia impartida el 11 de diciembre de 2012 en el XX Seminario de Arqueología Clásica. Iconografía del Mundo Clásico organizado por el Dpto. de Ciencias y Técnicas Historiográficas y Arqueología de la U.C.M., bajo la dirección de la Dra. Isabel Rodríguez López.
} 


\section{La legitimación ptolemaica del poder}

La ocupación persa de Egipto, llevada a cabo por Cambises en el año 525 a.C., constituyó el último episodio de un largo período de luchas internas y la primera de las diversas invasiones extranjeras que marcarían el destino del país a partir de entonces. La llegada de Alejandro Magno, no obstante, fue presentada por el general macedonio no como una nueva conquista, sino como una liberación. Aunque es probable que el objetivo inicial de Alejandro fuese, simplemente, debilitar al Imperio persa, la riqueza e importancia estratégica de los territorios conquistados, llevó a sus sucesores a continuar y consolidar la labor legitimadora que ya iniciara el propio Alejandro en el valle del Nilo.

Bajo el poder ptolemaico, Egipto se convirtió en uno de los reinos independientes surgidos del imperio macedonio. Al igual que otras dinastías nacidas del reparto territorial tras la muerte de Alejandro, el objetivo de los nuevos gobernantes fue consolidar este nuevo reino dentro del entorno mediterráneo y alcanzar una posición dominante a través de una potente política exterior. La integración con el elemento autóctono del nuevo reino egipcio no fue necesaria pues esto habría supuesto un descrédito en el entorno helenístico y únicamente se recurrió a la reconciliación, sin que, en ningún momento, se pretendiera su participación en el gobierno del país. Es muy significativo, en este sentido, el hecho de que en ciudades como Naucratis estuviesen prohibidos los matrimonios entre griegos y egipcios ${ }^{2}$.

Ptolomeo I, fundador de la dinastía, se autodenominó $\Sigma \omega \tau \eta ́ p$-Soter, Salvadorsubrayando, de este modo, la herencia de Alejandro como liberador de la dominación persa. Desde un punto de vista económico, la política ptolemaica buscó la optimización de los recursos del fértil valle del Nilo para consolidar la posición de Egipto en el entorno de las monarquías helenísticas; no obstante, desde un punto de vista simbólico, esta idea de salvadores se esgrimió como contraste con la dominación persa, y se promocionaron tanto la cultura como el arte e, incluso, la religión egipcia, que, a través del culto isiaco, se había difundido ya en territorio heleno y estaba destinada a expandirse por todo el Mediterráneo ${ }^{3}$.

Estas concesiones simbólicas no se vieron reflejadas en las demandas populares, pues la política y la administración del país se concentraron en manos griegas ${ }^{4}$. La integración de los nuevos dirigentes formó parte, en realidad, de una estudiada estrategia de legitimación del poder en el interior del país; casi podría afirmarse que la cultura egipcia se mantuvo, en gran parte, gracias al afán legitimador de la dinastía ptolemaica, que se sirvió de las fórmulas de legitimación tradicional faraónicas para presentarse como continuadores de la dilatada historia egipcia. Pero la administración del país fue netamente griega y así se deduce del control de los recursos mediante estructuras propias de la tradición helena, como la acuñación de

\footnotetext{
${ }^{2}$ A. K. Bowman, Egypt after the Pharaohs, 332 BC-AD 642: from Alexander to the Arab conquest, Berkeley, University of California Press, 1986, p. 146.

${ }^{3}$ M. A. ARroyo, «Isis y Serapis: Legitimadores de la realeza en época ptolemaica». En Boletín de la Asociación Española de Egiptología (B.A.E.D.E.), nº 9, año 1999, p. 157-174.

${ }^{4}$ J. OnIANS, Art and Thought in the Hellenistic Age. The Greek World View. 350 a.C.-50 b.C., Londres, Thames and Hudson, 1979, p. 71.
} 
moneda y el consiguiente sistema de transacciones introducido entonces en Egipto ${ }^{5}$; en el mismo sentido, cabe destacar también el cobro de impuestos por arrendamiento, que facilitaba la recaudación; asimismo, el Estado se adueñó de las tierras de los santuarios pasando así a administrar la formidable riqueza monopolizada hasta el momento por el estamento sacerdotal.

Las reacciones del pueblo egipcio, si bien, en un principio, resultaron favorables a Alejandro y contrarias a la dominación persa, fueron muy dispares y condicionaron la actuación de la dinastía ptolemaica. Cabe citar ahora las palabras de Colin Walter con respecto a la vida cotidiana de los egipcios y a la transformación sufrida tras la conquista ptolemaica:

...los egipcios no eran ya dueños de su propio destino y [...] desde el punto de vista político y comercial, su país se había integrado en el mundo mediterráneo, pero, en lo social y en lo cultural, permanecieron fieles a sí mismos, sin que les afectaran profundamente las costumbres y las actitudes de los nuevos gobernantes ${ }^{6}$.

La ciudad de Alejandría simbolizó este nuevo orden en Egipto: la propia personalidad de la nueva urbe, fundada por Alejandro, definió el helenismo de la dinastía subrayado por la presencia del cuerpo de Alejandro ${ }^{7}$. Durante el reinado de la última de las mandatarias ptolemaicas, Cleopatra VII Filópator, Alejandría conservaba aún ese simbolismo helenístico, no obstante, la imbricación de ambas identidades -helena y egipcia- era ya tal que, en el ámbito mediterráneo, la ciudad fue también símbolo de lo egipcio y, por extensión, de la misma Cleopatra. Así, esta urbe encarnó la grandeza, la riqueza, el lujo y la depravación que la sesgada y subjetiva visión de historiadores posteriores atribuyeron a la corte macedonia y, particularmente, al entorno de la reina.

\subsection{Alejandro Magno y la iconografía del poder}

Alejandro Magno fue consciente de las particulares necesidades de legitimación del territorio egipcio. Por una parte, era preciso consolidar la presencia macedonia tras la nueva conquista y, por tanto, asentar su imagen entre la incipiente población helena. Por otro lado, el propio Alejandro observó la importancia de los mecanismos de legitimación autóctonos y, no solo su trascendencia social, sino también la extraordinaria fuerza y pervivencia de los mismos a lo largo de la historia de Egipto; por ello, decidió presentarse a sí mismo como sucesor de la

\footnotetext{
${ }^{5}$ C. HERRERO, Introducción a la numismática antigua. Grecia y Roma, Madrid, Complutense, 1994, p. 157-158.

${ }^{6}$ C. WAlters, «El Egipto Ptolemaico», p. 99. En A. CotTerell (coord.), Historia de las Civilizaciones Antiguas. Egipto, Oriente Próximo, Barcelona, Crítica, 1987, $2^{a}$ ed, p. 90-99.

${ }^{7}$ El cadáver de Alejandro fue trasladado a Egipto gracias a la astucia de Ptolomeo I que desvió la comitiva fúnebre cuando se dirigía a la necrópolis de Egas. A.B. LLOYD, «El Período Ptolemaico. 332-30 a.C.», p. 524. En I. SHAw (ed.), Historia del Antiguo Egipto, Madrid, Esfera de los Libros, 2007, p. 511-540.
} 
tradición faraónica y, en este sentido, es especialmente revelador el episodio del oasis de Siwa, donde se intituló como Hijo de Amón.

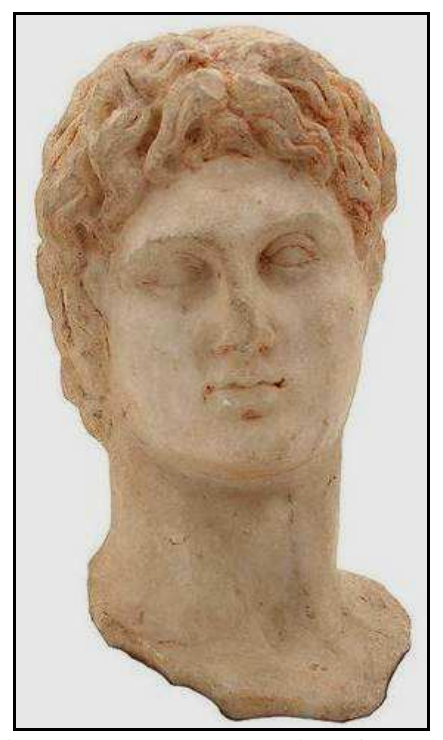

Fig. 1. Alejandro. 332-323 a.C. El Cairo, Museo Egipcio.

Imagen: The Global Egyptian Museum - http://www.globalegyptianmuseum.org (30/03/2013)

La imagen tradicional de Alejandro, fijada por Leochares y Lisipo y difundida por todo el entorno occidental, también se propagó en Egipto como parte del programa legitimador destinado al entorno helenístico. En este sentido, es significativa una pieza de pequeño tamaño (apenas $20 \mathrm{~cm}$. de altura) procedente de Thumuis -actual Tell El-Timai-, en el Bajo Egipto, y conservada en el Museo Egipcio de El Cairo (Fig. 1). Si bien de peor factura que otros ejemplares, como la magnífica cabeza conservada en el Museo de la Acrópolis (Fig. 2), en Atenas, es indudable la ejecución del rostro del joven Alejandro con el pelo ensortijado, los labios carnosos y la profunda mirada que caracterizó el prototipo escultórico aludido.

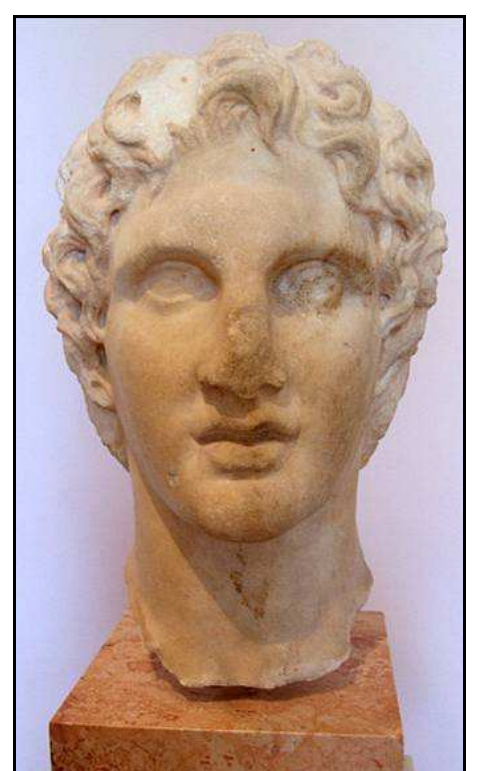

Fig. 2. LEOCHARES / LISIPO?. Alejandro. 332-323 a.C. Atenas, Museo de la Acrópolis. Imagen: Bajo licencia de Creative Commons Attribution-Share Aliked 2.5 Generic (09-092013) Autor: Marsyas, 07.04.2007 
La visita a Siwa constituyó un gesto simbólico dirigido expresamente al pueblo egipcio. En este pequeño oasis existían diversos templos: el más arcaico fue edificado por Amasis (570-526 a.C. $)^{8}$ y sirvió como sede de una guarnición local ${ }^{9}$; otro templete posterior se construyó bajo el mandato de Nectanebo II (360-342 a.C. ${ }^{10}$. Amasis había sido el último faraón que completó su mandato con anterioridad a la derrota frente a los persas; tras su muerte, en el año 526 a.C., su sucesor, Psamético III (526-525 a.C.), apenas permaneció un año en el poder antes de ser derrotado por Cambises. Este ambicioso soberano persa también se propuso la conquista de Nubia y de los diferentes oasis integrados en el territorio egipcio, particularmente, como más tarde haría también Alejandro, Cambises envió un ejército al oráculo de Amón en Siwa; sin embargo, esta simbólica expedición terminó en catástrofe y el ejército persa desapareció en el desierto durante la infructuosa búsqueda de los templos del dios tebano ${ }^{11}$. Tras el breve paréntesis de las dinastías XXVIII (404-399 a.C.), XXIX (399-380 a.C.) y XXX (380-342 a.C.), Nectanebo II sucumbió definitivamente ante el poderío de Artajerjes III ${ }^{12}$. Su figura también estuvo particularmente vinculada a los templos de Siwa, no solo por la edificación del citado templete, sino también por su particular devoción ${ }^{13}$. Si bien Nectanebo encarnaba la derrota definitiva ante los persas, con la visita al oasis de Siwa Alejandro superaba la prueba que acabó con el ejército de Cambises y rendía, además, homenaje a sus predecesores -Amasis y Nectanebo- restaurando, simbólicamente, el poder egipcio perdido frente a los invasores.

Además de este simbolismo político, la vinculación del joven Alejandro con Amón ejemplifica también la utilización del aparato protocolario egipcio para legitimar el poder dinástico macedonio, pues Amón simbolizaba el dominio faraónico. Desde el Reino Medio, de la mano de Amenemhat I y sus sucesores, esta divinidad conocida ya en los Textos de las Pirámides y definida como "Lo Oculto”, se vinculó con el poder político; posteriormente, en el Reino Nuevo, bajo el mandato de los monarcas tebanos, se consolidó como sustento simbólico de la monarquía egipcia ${ }^{14}$, status que, a excepción del paréntesis amarniense (ca. 13461333 a.C.), conservaría hasta el período tardío. En época ptolemaica, se identificó con Zeus, dios preponderante del panteón greco-latino, hasta tal punto que llegó a generarse un arquetipo iconográfico sincrético, Zeus-Amón, que aunaba la imagen

\footnotetext{
${ }^{8}$ En las fechas referidas a Egipto se ha seguido la publicación del Museo Egipcio de El Cairo (1999), The Treasures of the Egyptian Museum, elaborada según los estudios de John Baines y Jaromir Málek (1988) y de Jügen von Beckerath (1984), con el fin de mantener un criterio unificado desde el punto de vista cronológico.

${ }^{9}$ R. SCHUlZ y M. SEIDEL (ed.), Egipto. El mundo de los faraones, Madrid, Könemann, 1997, p. 274.

${ }^{10}$ B.G. Trigger, B.J. Kemp, D.B. O'Connor y A.B. Lloyd, Ancient Egypt. A Social History, Cambridge, Cambridge University Press, 2001, p. 345.

${ }^{11}$ N. Grimal, Historia del Antiguo Egipto, Madrid, Akal, 2004, 2a ed, p. 394-395 y 399.

${ }^{12}$ A.B. LLOYD, «La Baja Época. 664-332 a.C.», p. 502-503. En I. SHAW. 2007: 482-510.

${ }^{13}$ A. Roullet, The Egyptian and Egyptianizing Monuments of Imperial Rome, Leiden, E.J. Brill, 1972, p. 15.

${ }^{14}$ E. Castel, Gran Diccionario de Mitología Egipcia, Madrid, Alderabán, 2001, p. 46-51.
} 
barbada del dios heleno con los cuernos de carnero que aludían a la visión zoomorfa de la deidad egipcia (Fig. 3).

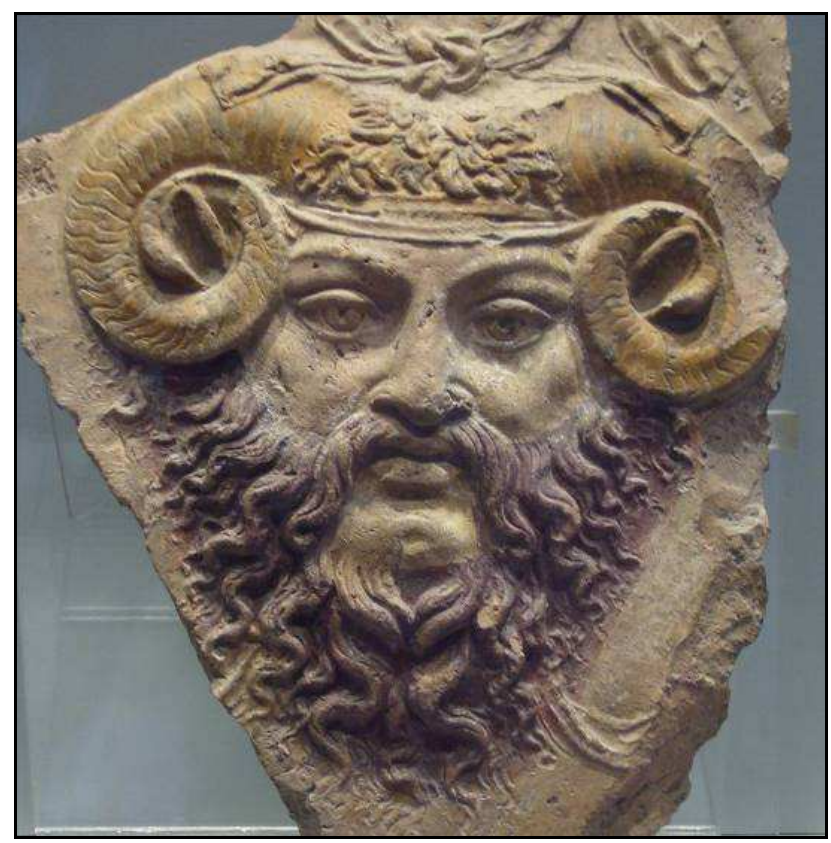

Fig. 3. Júpiter-Amón. Siglo I d.C. Roma, Museo Barracco. Imagen: Bajo licencia de Creative Commons Attribution-Share Aliked 3.0 Unported (11-09-2013)

La filiación de Alejandro con Amón vinculó a aquel con la tradición helena a través de su relación con Zeus, pero, además, remitía a la divinización de la monarquía egipcia. Durante el Reino Nuevo, aquellos faraones que precisaron reforzar su legitimidad se apoyaron en el dios tebano y desarrollaron todo un programa iconográfico que subrayaba la paternidad divina ${ }^{15}$. Si bien Alejandro no se inspiró en estos elaborados programas, sí se hizo representar en compañía de su padre Amón en el templo de Luxor; y es precisamente en este templo, en el que Alejandro emprendió la reconstrucción del santuario de la embarcación del dios ${ }^{16}$, donde el nuevo faraón se muestra de acuerdo con los patrones iconográficos propios del arte egipcio, en presencia y compañía del dios mismo (Fig. 4).

\footnotetext{
${ }^{15}$ La primera edificación que conmemoró el alumbramiento divino fue la denominada Sala del Nacimiento, en el templo funerario de la reina Hatshepsut (ca. 1479-1458 a.C.), "Hija de Amón”, en Deir-el-Bahari; otras versiones del mismo mito aparecen en Luxor y en Karnack, bajo Amen-Hotep III ( $c a$. 1387-1350 a.C.) y Ramsés II (ca. 1279-1212 a.C.), respectivamente. El mito del nacimiento divino contribuyó a subrayar la divinidad del monarca y, especialmente en el caso de Hatshepshut y Amen-Hotep III, a legitimar su presencia en el trono de las Dos Tierras.

${ }^{16}$ Así en A. SiliotTi, Egipto. Templos, hombres y dioses, Barcelona, Óptima, 2001, p. 166. En el templo de Luxor se rendía culto también al $k a$ del faraón. El $k a$ fue uno de los componentes de la compleja concepción espiritual egipcia. Era concebido como una especie de fuerza vital, intrínseca a cada individuo; en el caso del faraón, su $k a$ estaba estrechamente vinculado con la divinidad, se suponía que nacía con el rey y era considerado como su gemelo, de hecho, se ha relacionado con la costumbre de adorar la placenta del vástago real. H. FRANKFORT, Reyes y dioses, Madrid, Revista de Occidente, 1976, p. 93-102. Esta adoración del ka real era también una forma de legitimación del poder.
} 


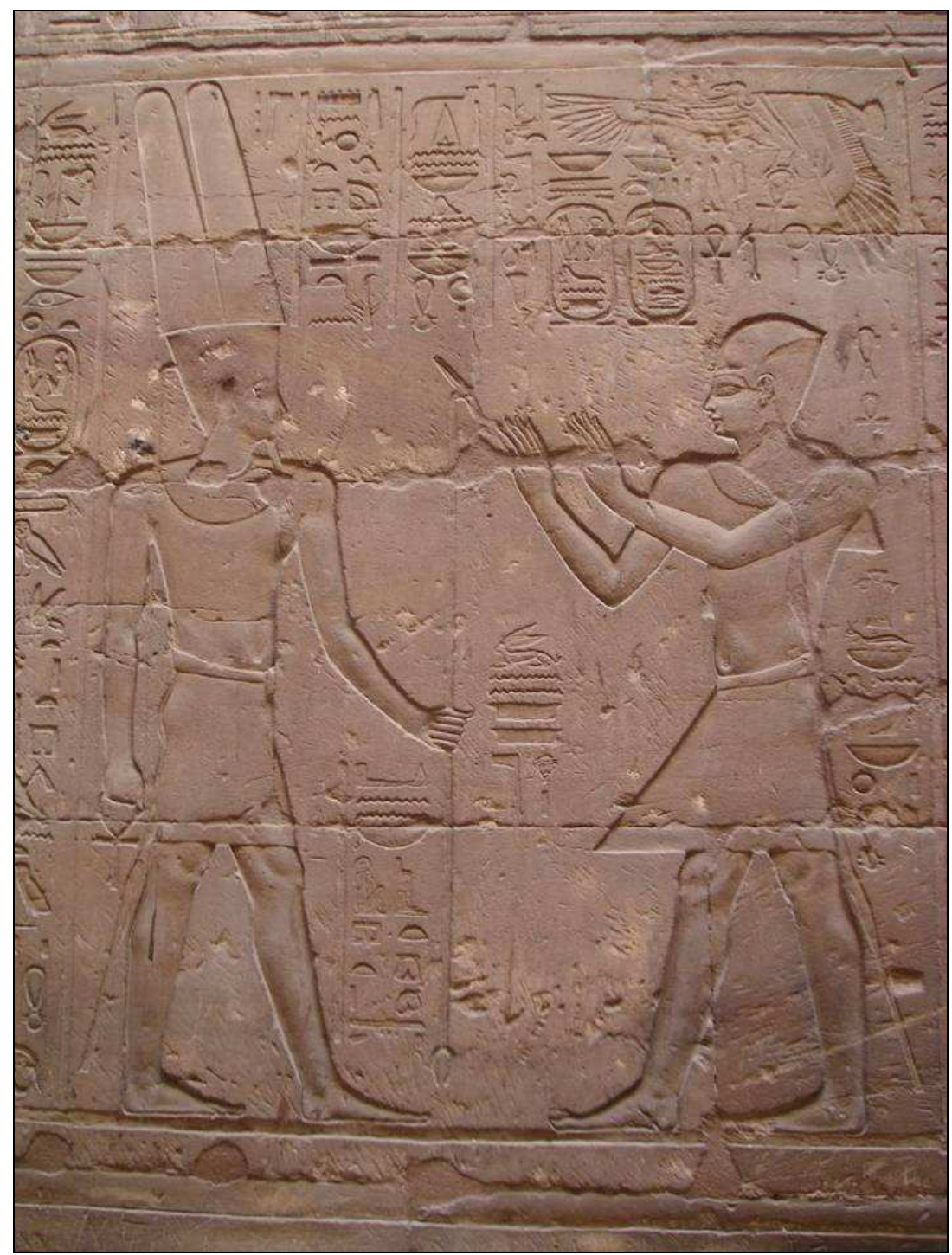

Fig. 4. Alejandro Magno ante el dios Amón. 332-323 a.C. Templo de Luxor. Imagen: Bajo licencia de Creative Commons Attribution-Share Aliked 3.0 Unported (12-10-2013). Autor: Neithsabes

Esta iconografía destinada a la legitimación del poder macedonio en Egipto presentaba a Alejandro según la tradicional perspectiva egipcia, con el torso desnudo, vestido tan solo con el acostumbrado faldellín y tocado con la corona azul $^{17}$, en actitud de adoración ante el dios, pero situado a su misma altura y con idéntica proporción, símbolo de la filiación con la divinidad que había caracterizado la visión de los faraones. La imagen, tal y como era tradicional, se completaba con la inscripción de los nombres reales que identificaban a Alejandro como Señor de las Dos Tierras y que, además de incluir una transliteración del nombre griego (Alksinders), incorporaron también epítetos tan significativos como Merimen (Amado de Amón $)^{18}$.

\footnotetext{
${ }^{17}$ Es la denominada Jeperesh. Si bien este tocado ha sido relacionado tradicionalmente con la indumentaria militar, parece ser que se trataba de una corona ceremonial empleada a partir de la dinastía XVIII (ca. 1550-1291 a.C.). E. CASTEL, Egipto. Signos y símbolos de lo sagrado, Madrid, Alderabán, 1999, p. 131-132.
}

${ }^{18}$ N. GRIMAL. 2004: 514. 


\subsection{Los sucesores de Alejandro y la consolidación del poder ptolemaico}

La consolidación del poder dinástico tras la muerte de Alejandro se asentó sobre las bases ya fijadas por el joven conquistador: se continuaron desarrollando y reelaborando las fórmulas autóctonas, al tiempo que la propia imagen de Alejandro, vinculada a la divinidad sincrética Zeus-Amón, pervivió como símbolo de la legitimidad de la dinastía entre la población helena y en el entorno de las monarquías helenísticas.

Durante el breve mandato de Filipo Arrideo, hermanastro y sucesor de Alejandro (323-317 a.C.), se prosiguió con la remodelación de los santuarios tebanos de Amón. Particularmente significativa es la edificación de la Capilla de Parada (Fig. 5), inspirada en otra de época de Tutmés III (ca. 1479-1425 a.C.). Estas capillas eran empleadas para el transporte de las barcas de la tríada tebana hasta el templo de Luxor, donde se simbolizaba la unión divina y el nacimiento del heredero ${ }^{19}$, ceremonia estrechamente relacionada con la divinización del poder faraónico. En el lado exterior de la pared meridional de esta capilla, el hermanastro de Alejandro fue representado por artistas egipcios en el momento de su coronación de manos de los dioses Thot y Horus.

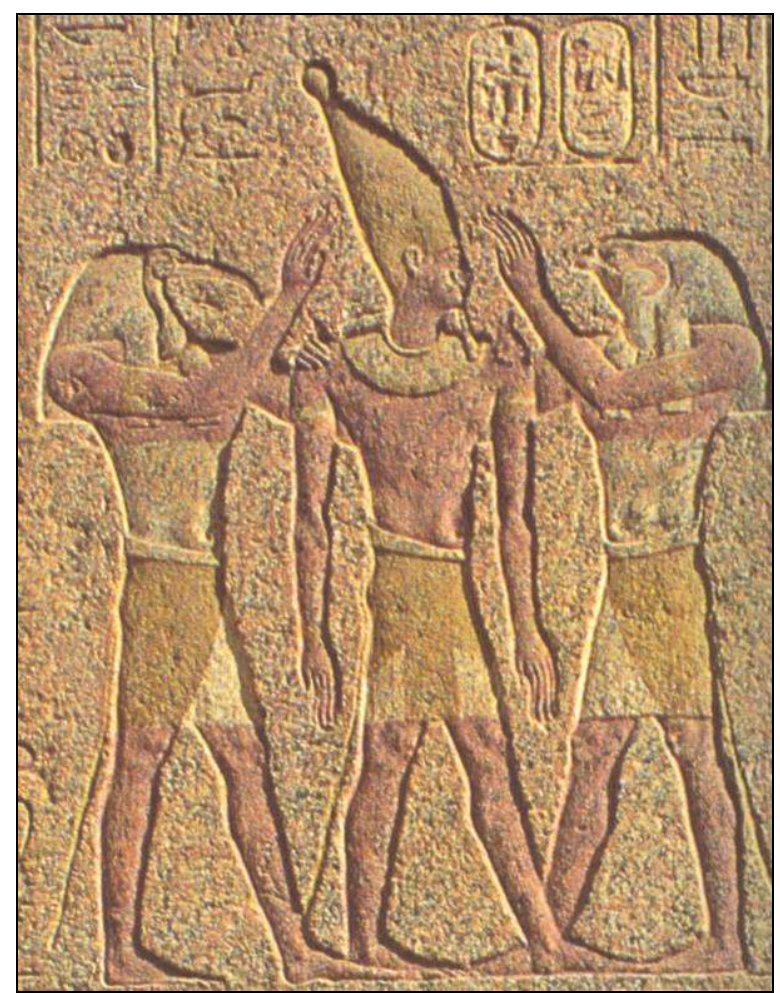

Fig. 5. Filipo Arrideo coronado por Thoth y Horus. 323-317 a.C.

Capilla de Filipo Arrideo. Templo de Karnack.

Imagen: A. SILIOTTI, Egipto. Templos, hombres y dioses, Barcelona, Óptima, 2001, p. 181.

El vínculo con las últimas dinastías faraónicas, fijado a través de fórmulas iconográficas tradicionales, se consolidó, por tanto, desde los primeros años de la dominación macedonia; la inspiración en obras de arte del Reino Nuevo, en este

${ }^{19}$ A. SiLIOTTI. 2001: 181. 
caso, la capilla de Tutmés III, y la presencia de diferentes divinidades del panteón egipcio, así lo prueba. La legitimación del poder ptolemaico en el entorno helenístico, no obstante, respondía al vínculo del fundador de la dinastía, Ptolomeo I, con Alejandro Magno. Por ello, el prototipo iconográfico que fijó la imagen del conquistador continuó difundiéndose, incluso, en las acuñaciones monetarias, cargado ahora de emblemas que subrayaban la divinidad y excepcionalidad del general macedonio. En el anverso de un tetradracma de Ptolomeo I, conservado en el Museo Arqueológico Nacional de Madrid, puede apreciarse el rostro de Alejandro Magno, tocado con una diadema y una piel de elefante y adornado con la égida y el cuerno del carnero de Amón (Fig. 6). Esta compleja iconografía muestra a un Alejandro soberano de la tierra de Egipto, simbolizada por la piel de elefante (v. infra); asimismo, en opinión de Fernando de Olaguer-Feliú, la égida alude a su calidad de "defensor" y, en conjunto, esta elaborada iconografía simboliza su “capacidad guerrera, su fuerza, su poder, su majestad y sus altos pensamientos" No obstante, cabe destacar también la divinización de su efigie en estrecha relación con la deidad sincrética Zeus-Amón, patente en la representación del cuerno de carnero.

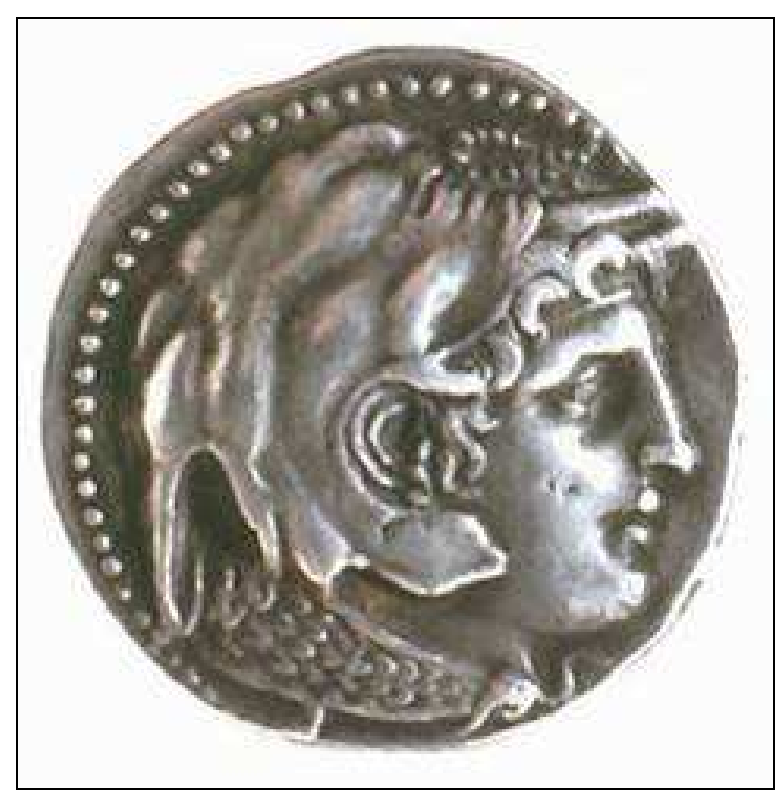

Fig. 6. Tetradracma. Ptolomeo I (305-282 a.C). Madrid, Museo Arqueológico Nacional.

Imagen: The Global Egyptian Museum - http://www.globalegyptianmuseum.org (02/09/2013)

En el reverso de esta moneda, aparece la diosa Atenea, estante, portando escudo y lanza y acompañada por un águila ${ }^{21}$, atributo que remite de nuevo al Crónida. Por tanto, en los inicios de la dinastía, la imagen de Alejandro divinizado, en relación con dioses tanto egipcios como griegos, sirvió ya en sí misma como un fuerte

${ }^{20}$ F. DE Olaguer-Feliú, Alejandro Magno y el Arte. Aproximación a la personalidad de Alejandro Magno y su influencia en el Arte, Madrid, Encuentro, 2000, p. 113.

${ }^{21}$ The Global Egyptian Museum, http://www.globalegyptianmuseum.org/record.aspx?id=8626. (11/09/13). Ficha elaborada por el Departamento de Numismática y Medallística, Museo Arqueológico Nacional de Madrid: C. Alfaro; P. Otero; C. MARCos. "Atenea de pie, mirando hacia la derecha y portando un escudo y una lanza. En el campo, a la izquierda, monograma y águila". 
elemento de legitimación, especialmente de cara a la población helena. Pero esta labor de imbricación cultural no solo afectó a la imagen de los mandatarios, sino que implicó también a las divinidades. La vinculación con Amón, que fue cultivada tanto por Alejandro como por sus inmediatos sucesores, se mantuvo; no obstante, la popularidad del mito osiriaco entre la población autóctona, unida a la vinculación de la tríada protagonista del mito con el poder, provocó una revitalización de un nuevo culto helenizado y sincrético.

En este sentido, es significativa la campaña de helenización de la figura de Osiris. Esta se produjo mediante la creación de una nueva divinidad que se inspiraba en una deidad menfita, Osorapis, una forma del toro Apis que aunaba la adoración del ba del dios Ptah con el propio Osiris, al que se asimilaba el animal tras su muerte. La iconografía de esta divinidad presentaba a una figura humana con cabeza de toro y era adorada en el Serapeum de la ciudad ${ }^{22}$. Esta deidad estaba también relacionada con la fertilidad y, en tanto el faraón era el garante de aquella, también estaba vinculada con el poder político. Bajo el mandato de Ptolomeo I Soter se instituyó y fijó la imagen de Serapis, inspirada en esta divinidad menfita. Según el relato de Plutarco:

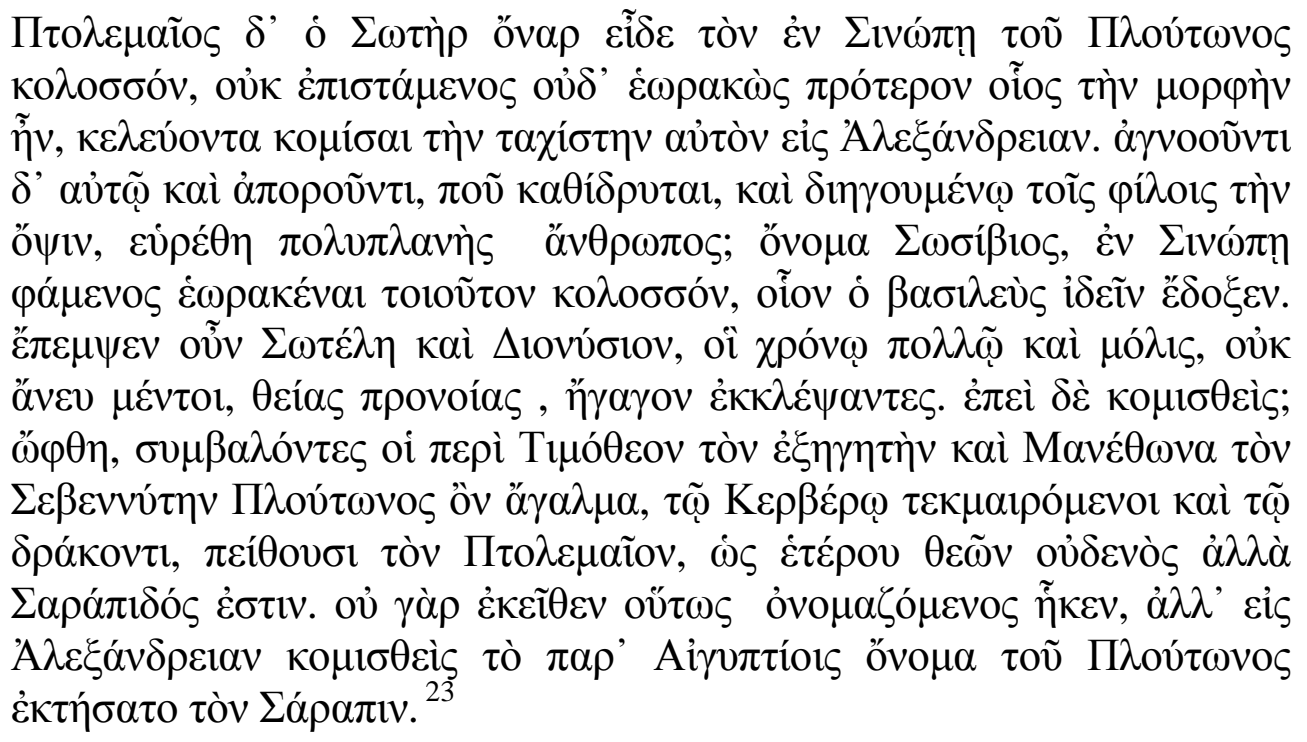

${ }^{22}$ E. CASTEL. 1999: 67-69.

23 "Ptolomeo Soter vio en sueños al coloso de Plutón que estaba en Sinopis. Ignoraba su existencia, no sabiendo su forma, no habiéndolo visto jamás. En esta visión le ordenó el dios hiciera transportar lo antes posible esta gigantesca figura a Alejandría. Ptolomeo, ignorando como ignoraba el lugar en que se erigía, se encontró en apuro y, al relatar la visión a sus amigos, halló entre ellos un hombre llamado Sosibios que había viajado mucho. Éste declaró que en Sinopis había visto un coloso parecido al que el rey vio en su sueño. Entonces Ptolomeo envió a Soteles y Dioniso, y estos dos hombres, tras muchas penas y largo tiempo, a pesar de contar con la ayuda de una providencia divina, consiguieron llevarse furtivamente al coloso. Tan pronto fue visible aquella figura transportada, Timoteo y Manetón el Sebenita conjeturaron por el Cerbero y el dragón que poseía como emblemas, que se trataba de la estatua de Plutón, persuadiendo a Ptolomeo que no representaba a otro dios sino a Serapis. En el lugar de donde venía no llevaba ciertamente este nombre, pero una vez transportada a Alejandría se la designó de este modo, puesto que recibió por parte de los egipcios el nombre de Serapis, que es precisamente del que se sirven para designar a Plutón”. Plutarco, De Iside et Osiride, 28 (361f-362a). Transcripción: PlutARCH, De Iside et Osiride, Gregorius N. Bernardakis, en Perseus Digital Library: 
El texto ejemplifica la trascendencia dada a la "creación" de nuevas divinidades que aunaran las tradiciones griega y egipcia, divinidades sincréticas asociadas además al poder político, que facilitaban la legitimación del poder en ambos ámbitos culturales. Este episodio narrado por Plutarco muestra el interés del primer miembro de la dinastía por iniciar la labor legitimadora en relación con la religión egipcia y, particularmente, en estrecho vínculo con la tríada osiriaca. En el caso de Serapis, su asociación con el poder radicaba en su origen osiriaco, pues Osiris fue considerado el padre del faraón, quien se encarnaba en Horus, hijo de Isis y de Osiris. No obstante, según una tradición, el propio Alejandro habría sido el fundador del Serapeo de Alejandría, inaugurando de este modo el culto a este dios con anterioridad al mítico sueño de Ptolomeo ${ }^{24}$; mediante esta tradición, de nuevo, se vinculaba al conquistador macedonio con la legitimación política, aunando tanto la visión egipcia como la helenística a través de la mitificación de su corto mandato.

En lo que respecta a la iconografía de esta nueva divinidad, la concepción estética helena declinó la visión híbrida del Osorapis menfita, cuerpo humano con cabeza de animal, para recrear una divinidad más vinculada con el Osiris antropomorfo. La creación de la divinidad, cuidadosamente orquestada, se puso en manos de Timoteo y Manetón para la adaptación del culto menfita, al tiempo que Demetrio de Phalenon elaboró un cuidadoso ritual helénico; desde el punto de vista iconográfico, el escultor Briaxis creó la nueva imagen de la divinidad, estrechamente relacionada con los majestuosos Zeus helenísticos barbados, y adornada con los atributos propios de Plutón, tal y como se describía en la experiencia onírica de Ptolomeo.

El culto se instauró en un nuevo templo, diseñado por Parmeniscus, mientras la devoción de los monarcas facilitaba la difusión del culto entre las clases altas de la población griega ${ }^{25}$. La asimilación de esta deidad en la tradición helena fue tal que se llegó a crear una leyenda según la cual Apis fue considerado un mítico rey del Peloponeso, hijo de Telédice y de Foroneo, asesinado por Etolo o por Telquis y Telxión -según versiones-; a su muerte, era vengado por Argos y divinizado bajo el nombre de Serapis ${ }^{26}$. La iconografía de Serapis presenta a un dios entronizado, acompañado de Cerbero y tocado con el cálathos ( $\kappa \alpha ́ \lambda \alpha \theta o \varsigma)$, una cesta para la recolección de cereales que aludía también a Osiris en tanto este estuvo estrechamente relacionado con la fertilidad agrícola. Esta divinidad, completamente antropomorfa, como lo era Osiris, presentaba por tanto una imagen helenizada acorde con la mentalidad helena (Fig. 7).

http://www.perseus.tufts.edu/hopper/ (20/09/13). Traducción según PLUTARCO, Isis y Osiris, Traducción de Mario Meunier. Según edición de 1930. Isis y Osiris. (Versión hecha sobre la traducción francesa, con prefacio, prolegómenos y notas de Mario Mecnier por F. Gallach Pales), Barcelona, Obelisco, 2006.

${ }^{24}$ M. LÓPEZ, «Isis y Sarapis: Difusión de su culto en el mundo grecorromano», p. 164-165. En Minerva. Revista de Filología Clásica, no 6, año 1992, p. 161-192.

${ }^{25}$ Un elaborado estudio acerca del diseño del nuevo culto y su incidencia en la nueva oligarquía helena en T. A. BRADY, Serapis \& Isis. Collected Essays, Chicago, Ares, 1978, p. 10-12.

${ }^{26}$ P. GRIMAL, Diccionario de Mitología Griega y Romana, Barcelona, Paidós Ibérica, 1981, p. $34-$ 35 . 


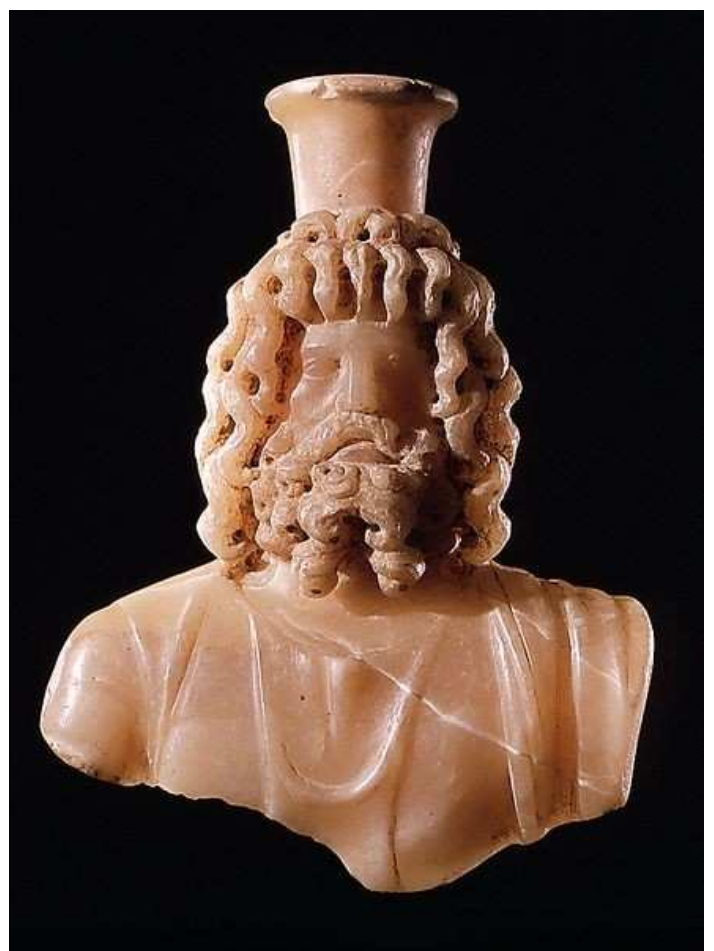

Fig. 7. Serapis. S. II d.C. Hildesheim, Pelizaeus Museum.

Imagen: The Global Egyptian Museum - http://www.globalegyptianmuseum.org (05/09/2013)

Así pues, tanto Amón como este Serapis sirvieron para la legitimación de los nuevos mandatarios egipcios, pero, en el caso de sus consortes, la divinización se realizó a través de Isis, esposa de Osiris-Serapis. La identificación de las reinas ptolemaicas con la diosa se convirtió en una tradición para la dinastía macedonia iniciada por la esposa de Ptolomeo II Filadelfo (285-246 a.C. $)^{27}$, pero sería la última de las reinas de la dinastía, Cleopatra VII Filópator, quien se identificara con Isis de manera más subrayada, aprovechando la difusión del culto a la diosa en el Mediterráneo.

\section{Cleopatra VII Filópator}

\subsection{Numismática e imágenes helenísticas}

Cleopatra VII, última representante de la dinastía ptolemaica, conservó el vínculo con Alejandro Magno como elemento legitimador; esta particularidad puede apreciarse en sus acuñaciones monetarias, que siguieron las pautas fijadas por Ptolomeo I. Si bien la imagen de Alejandro Magno desapareció, se mantuvo el reverso vinculando con Zeus como una reminiscencia de la divinización del conquistador macedonio. Sirva como ejemplo una acuñación de la reina conservada en el Museo Arqueológico Nacional de Madrid, cuyo reverso presenta un águila sobre el rayo mirando hacia la izquierda ${ }^{28}$. Pero al margen de estos emblemas

\footnotetext{
${ }^{27}$ T. A. BRADY: 1978: 13.

${ }^{28}$ The Global Egyptian Museum. http://www.globalegyptianmuseum.org/record.aspx?id=8631. (23/09/13). Ficha elaborada por el Departamento de Numismática y Medallística, Museo Arqueológico Nacional de Madrid: C. AlfARO; P. Otero; C. MARCOS. “Anverso: cabeza de
} 
dinásticos, las acuñaciones solían mostrar un anverso con el rostro del soberano ya desde época de Ptolomeo I, quien también emitió series con su propia imagen; en el caso de la reina Cleopatra VII, estos pequeños retratos son una de las fuentes más fiables para vislumbrar el tan comentado rostro de la joven reina egipcia. Cleopatra VII eligió para este significativo soporte una representación helenística de sí misma. El semblante de la reina, tan controvertido por su mitificada belleza, puede apreciarse en estas acuñaciones desde una perspectiva naturalista y en absoluto idealizada (Fig. 8).

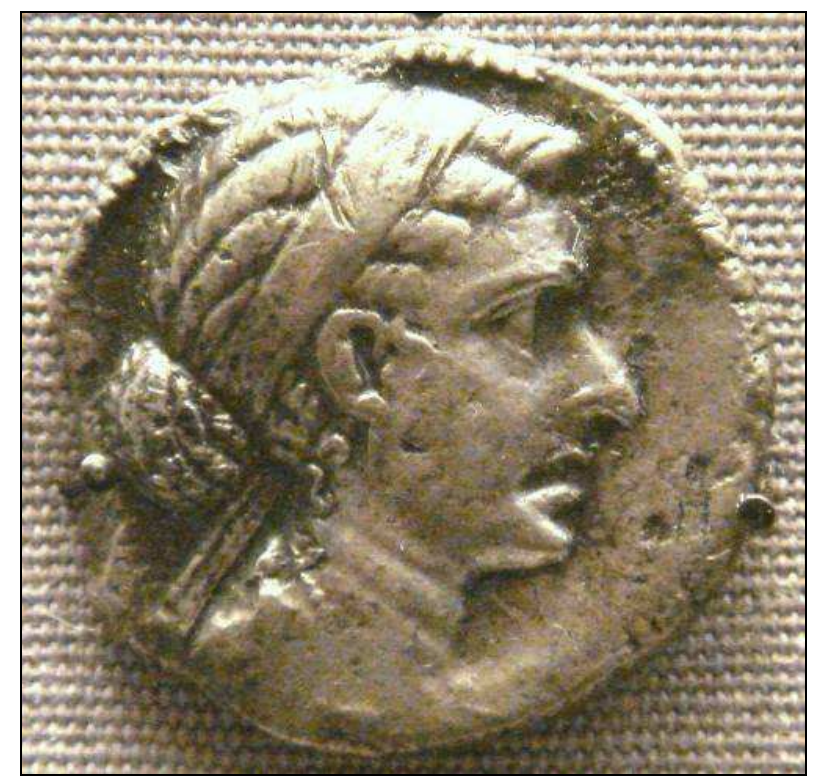

Fig. 8. Tetradracma. Cleopatra VII. 51-30 a.C. Londres, Museo Británico.

Imagen: Bajo licencia de Creative Commons Attribution-Share Aliked 3.0 Unported

(22/09/2013) Autor: PHGCOM

El cuño muestra a una mujer que luce un recogido con moño bajo, propio de las modas helenísticas, sin símbolo alguno de poder salvo una sencilla diadema; su rostro está dominado por una prominente nariz aguileña que, sin duda, debió de ser uno de los rasgos más característicos de sus facciones. Esta imagen difiere de la mítica belleza que la historiografía y el arte han transmitido de la famosa reina ptolemaica; no obstante, la proverbial belleza de la reina, sin duda, tuvo su origen no solo en una iconografía idealizada sino también en las fuentes. En este sentido, son particularmente significativas las palabras de Plutarco:

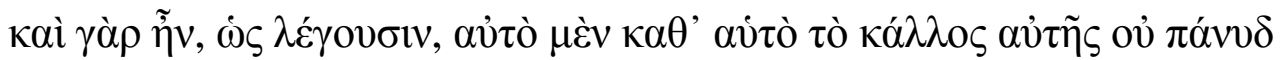

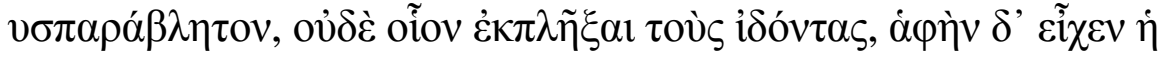

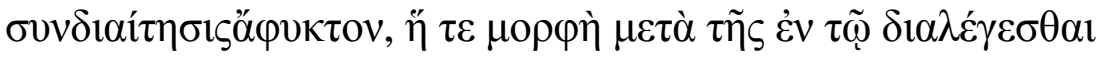

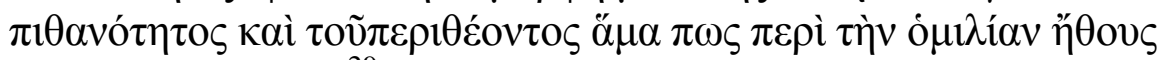

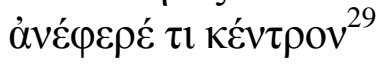

Cleopatra VII con diadema mirando hacia la derecha. Reverso: águila sobre el rayo mirando hacia la izquierda”.

29 "Según dicen, su belleza no era tal que deslumbrase o que dejase parados a los que la veían; pero su trato tenía un atractivo inevitable, y su figura, ayudada de su labia y de una gracia inherente a su conversación, parecía que dejaba clavado un aguijón en el ánimo." Plutarco, Antonio, XXVII, 2. 
El texto describe a una mujer dotada de un extraordinario atractivo y no tanto de una belleza física deslumbrante; su descripción sugiere que el poder de seducción de la reina radicaba en su actitud y su inteligencia, más que en su aspecto. La visión objetiva de sus rasgos en la numismática ha permitido vislumbrar el rostro de Cleopatra en ciertas obras de estilo helenístico.

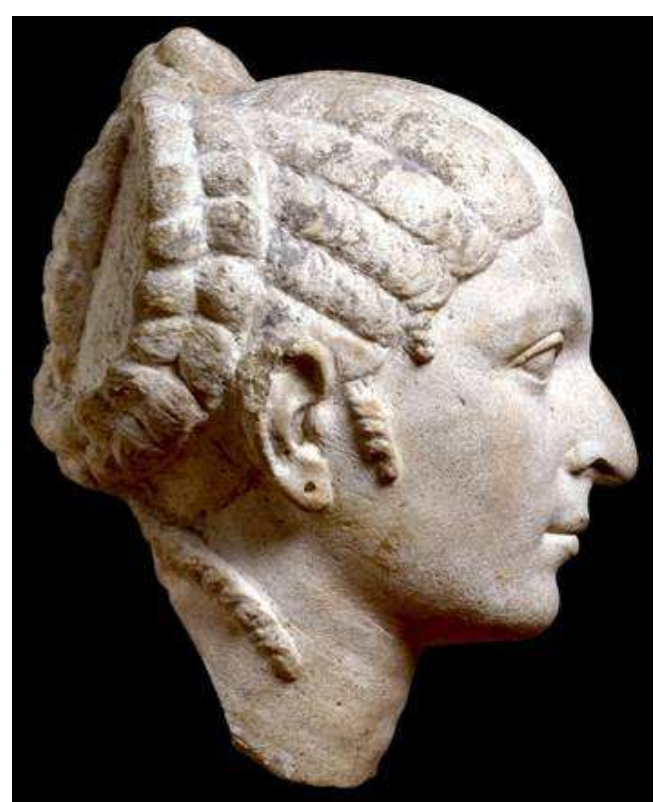

Fig. 9. Cleopatra VII?. 50-40 a.C. Londres, Museo Británico

Imagen: S. WALKER y P. HIGGS (ed.), Cleopatra of Egypt: from history to myth. Catálogo de la Exposición. Londres, The British Museum Press, 2001, p. 229, nº 210

Cabe destacar, entre este grupo, una pequeña cabeza de mujer conservada en el Museo Británico, de apenas $28 \mathrm{~cm}$. de altura, que ha sido identificada con Cleopatra VII Filópator precisamente por comparación con las acuñaciones monetarias (Fig. 9); el principal rasgo, la prominente nariz aguileña, así parece sugerirlo, si bien el peinado no se corresponde con el moño bajo que aparece en las monedas, sino con un elaborado recogido que, en cualquier caso, responde también a las modas helenísticas. Los orificios que presenta en los lóbulos de las orejas, sugieren que la escultura pudo ser adornada con piezas de metal, a modo de pendientes.

En el ámbito de la imagen helenística de la reina, podemos comentar también una cabeza de polémica atribución, que podría representar a las reinas Cleopatra I o Cleopatra II, y que ha sido datada en torno a los años 181-164 a.C., si bien ciertos autores consideran que puede tratarse de un retrato de Cleopatra VII Filópator ${ }^{30}$ (Fig. 10). Los rasgos, especialmente el tamaño de la nariz, la boca carnosa y con una pronunciada curvatura en el labio superior, e, incluso, los potentes pómulos,

Transcripción: PluTARCH, Plutarch's Lives, with an English Translation by Bernadotte Perrin, Cambridge, Harvard University Press, en Perseus Digital Library: http://www.perseus.tufts.edu/hopper/ (22/09/13). Traducción según PlUTARCO, Vidas paralelas. Demetrio-Antonio. Introducción, traducción y notas de Juan Francisco Martos Montiel, Madrid, Alianza, 2007.

${ }^{30}$ S. WAlKer y P. HigGS (ed.), Cleopatra of Egyp: from history to myth. Catálogo de la Exposición. Londres, The British Museum Press, 2001, p. 53. 
recuerdan las imágenes de Cleopatra VII en la numismática. En lo que respecta a los atributos iconográficos con los que solía mostrarse la reina en las efigies oficiales, Sally Ann Ashton ha definido la imagen de Cleopatra VII como tocada con el triple uraeus sobre la frente ${ }^{31}$; esta reiteración del símbolo real serviría para acentuar los rasgos legitimadores de este arcaico emblema y revela las dificultades de la reina para acceder al trono de Egipto en solitario. Esta cabeza del Museo Greco-Romano de Alejandría, si bien presenta una única cobra sobre la frente, muestra un círculo de ofidios como base de la imprescindible corona; en este caso, por tanto, la redundancia del simbolismo real se lleva a cabo en la base del tocado. Sus dimensiones $(80 \mathrm{cms})$ apuntan a una escultura colosal y su lugar de procedencia, Mazarita, localidad cercana a Alejandría, vinculan esta obra con la corte alejandrina.

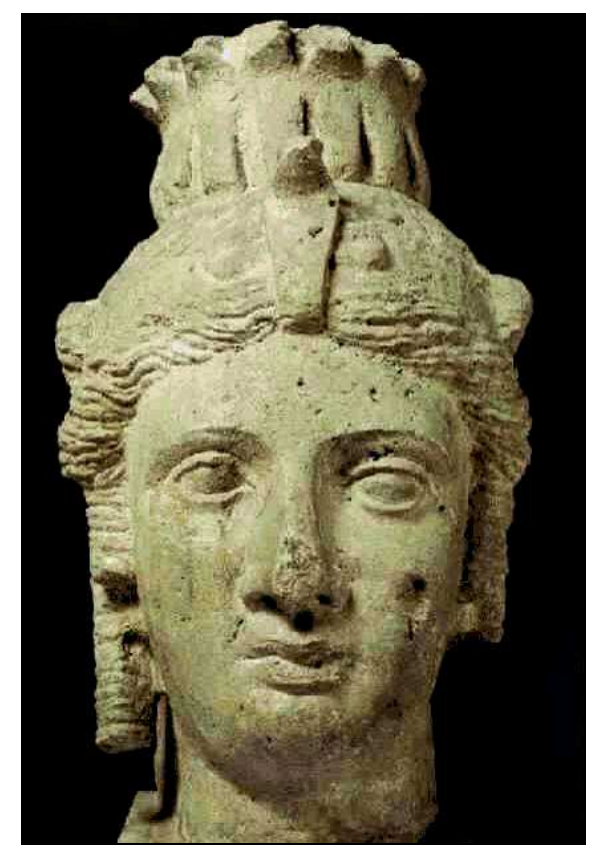

Fig. 10. Cabeza de una reina ptolemaica. 181-164 a.C.?. Alejandría, Museo Greco-Romano. Imagen: S. WALKER y P. HIGGS: 2001: 53, nº 17

El rostro de la reina denota un naturalismo propio del arte helenístico adornado, no obstante, por los ya descritos símbolos de poder faraónicos; este sincretismo artístico responde al carácter de una población helena asentada ya plenamente en el territorio egipcio e identificada con la ancestral cultura autóctona. Pero, si en el norte del país y el área de influencia alejandrina predominaron las formas helenizadas, en las poblaciones del Alto Egipto prevalecería la estética egiptizante. Sirva como ejemplo una cabeza conservada en el Brooklyn Museum de Nueva York (Fig. 11). A pesar del deterioro, puede apreciarse con claridad el detalle naturalista del trazado de los labios o los pómulos, no obstante, a diferencia de los recogidos helenísticos ya comentados, esta cabeza de Nueva York luce un peinado suelto que imita las tradicionales pelucas de tradición dinástica; asimismo, los ojos

\footnotetext{
${ }^{31}$ Acerca el triple uraeus y los atributos iconográficos más o menos precisos para identificar a Cleopatra VII, véase S.A. AsHTON, «Identifying the Egyptian-style Ptolemaic queens». En S. WALKER y P. HIGGS. 2001: 148-155.
} 
almendrados y dispuestos para contener, probablemente, piezas vidriadas, evocan la tradición egipcia. Sobre la frente, una leve diadema adornada con el triple uraeus sugiere que pueda tratarse de un retrato de la reina.

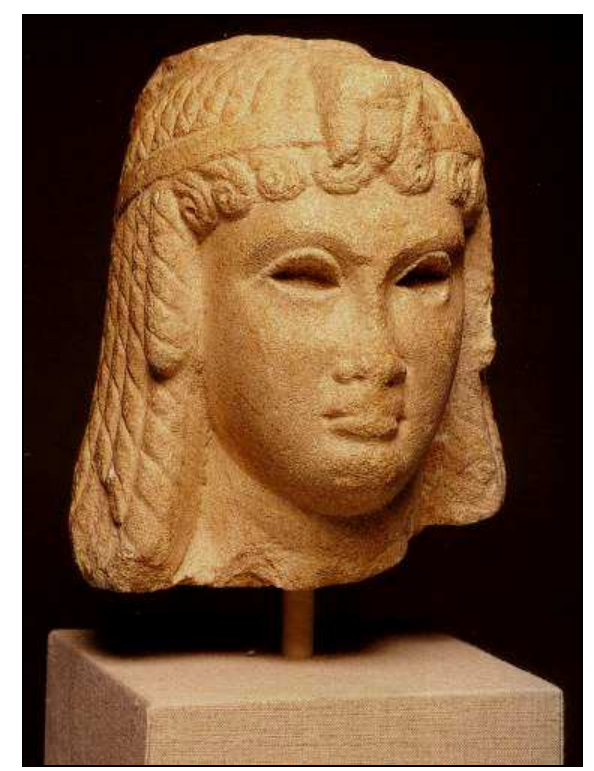

Fig. 11. Cleopatra VII?. 51-30 a.C. Nueva York, Brooklyn Museum. Imagen: S. WALKER y P. HIGGS. 2001: 164, nº 163.

De factura muy similar en lo que al rostro se refiere es la efigie conservada en el Museo Metropolitano de la misma ciudad, de apenas $60 \mathrm{~cm}$. de altura y procedencia desconocida (Fig. 12). El rostro presenta ciertos rasgos naturalistas, que adolecen, no obstante, del hieratismo propio del arte egipcio; el peinado, adornado con la consabida diadema de triple uraeus, recuerda también las tradicionales pelucas egipcias. Por otra parte, remite también a la estética helenística el tratamiento de las telas, si bien la reina luce la tradicional vestimenta egipcia anudada.

Este particular atuendo, que dejaba al descubierto los pechos, fue propio de la divinidad en la iconografía egipcia y, particularmente, constituyó la indumentaria habitual de Isis. El nudo había sido un símbolo de la diosa desde sus orígenes y, de hecho, existió un amuleto particularmente asociado a Isis, que simbolizaba una cuerda enlazada ${ }^{32}$. Desde un punto de vista iconográfico, el nudo sobre el pecho constituyó, también en la imagen greco-latina de la diosa, un atributo iconográfico muy significativo ${ }^{33}$. Resulta también significativo otro atributo relativo a la divinidad que adorna esta efigie de la reina: la cornucopia que sostiene con su brazo izquierdo, que, si bien puede considerarse una alusión a la fertilidad, fue un distintivo propio de la diosa Fortuna. La Tyché griega fue la casualidad divinizada; cada ciudad tuvo su Tyché, tocada con torres; Fortuna, por su parte, tuvo como atributos iconográficos el cuerno de la abundancia y un timón, simbolizando su poder para dirigir el rumbo de la vida. Ambas fueron

\footnotetext{
${ }^{32}$ Se trata del denominado nudo tit. E. CASTEL. 1999: 387-388.

${ }^{33}$ Un exhaustivo estudio acerca de la indumentaria tradicional de la diosa a partir de la época helenística en E.J. WALTERS, Attic grave reliefs that represent women in the dress of Isis, Princenton - Nueva Yersey, American School of Classical Studies at Athens, 1988, p. 5-11.
} 
representadas, habitualmente, ciegas. El sincretismo Isis-Fortuna tuvo en época helenística tal trascendencia que llegó a consolidarse una divinidad sincrética denominada Isityché o Isitiqué ${ }^{34}$.

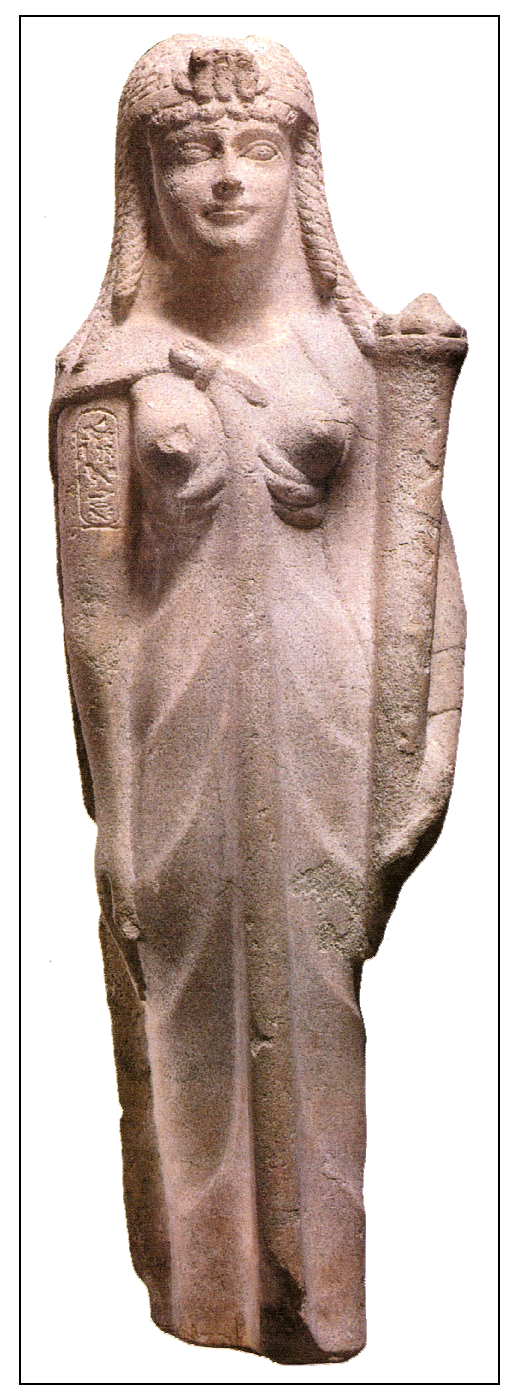

Fig. 12. Cleopatra VII. 51-30 a.C. Nueva York, Metropolitan Museum of Art. Imagen: S. WALKER y P. HIGGS. 2001: 165, nº 164.

Los atributos iconográficos descritos, así como la divinización de esta efigie en relación con la diosa Isis, sugieren una identificación con Cleopatra VII Filópator, que, en este caso, viene además confirmada por el cartucho inscrito sobre su brazo derecho ${ }^{35}$. La visión helenística de Cleopatra VII, por tanto, puede apreciarse en dos ámbitos esenciales: la numismática y la estatuaria. En la primera se han basado todos los estudios para tratar de recrear el rostro de la reina, pues las acuñaciones muestran las imágenes más fiables y realistas de su semblante. En lo que respecta a la escultura, no existe ningún ejemplar identificado con certeza; no obstante, de acuerdo con la numismática y los atributos icnográficos son varias las obras consideradas retratos de la reina

\footnotetext{
${ }^{34}$ P. GRIMAL. 1981: 518.

${ }^{35}$ Existen dudas sobre la autenticidad de esta inscripción. S. WALKER y P. HIGGS. 2001: 165.
} 
ptolemaica. En estas obras puede apreciarse la consolidación del sincretismo greco-egipcio a finales del período ptolemaico, tanto desde el punto de vista artístico, mediante la combinación de rostros naturalistas adornados con los atributos de la realeza egipcia, como también desde el punto de vista religioso, mediante la evocación de divinidades como Isitiqué, cuyo carácter sincrético recuerda la creación de Serapis en los inicios de la dinastía.

\subsection{Reina de Egipto}

La imagen de la reina como soberana de las Dos Tierras debió de difundirse en todo el territorio egipcio, pero, entre la población autóctona, al igual que ya hicieran el propio Alejandro Magno y los primeros ptolomeos, la imagen del poder tuvo que consolidarse de acuerdo con los parámetros del arte egipcio tradicional. En este sentido, el prototipo iconográfico ya comentado de Isitiqué se fijó también en modelos de corte egiptizante de los que es un buen ejemplo la escultura conservada en el Museo del Hermitage (Fig. 13).

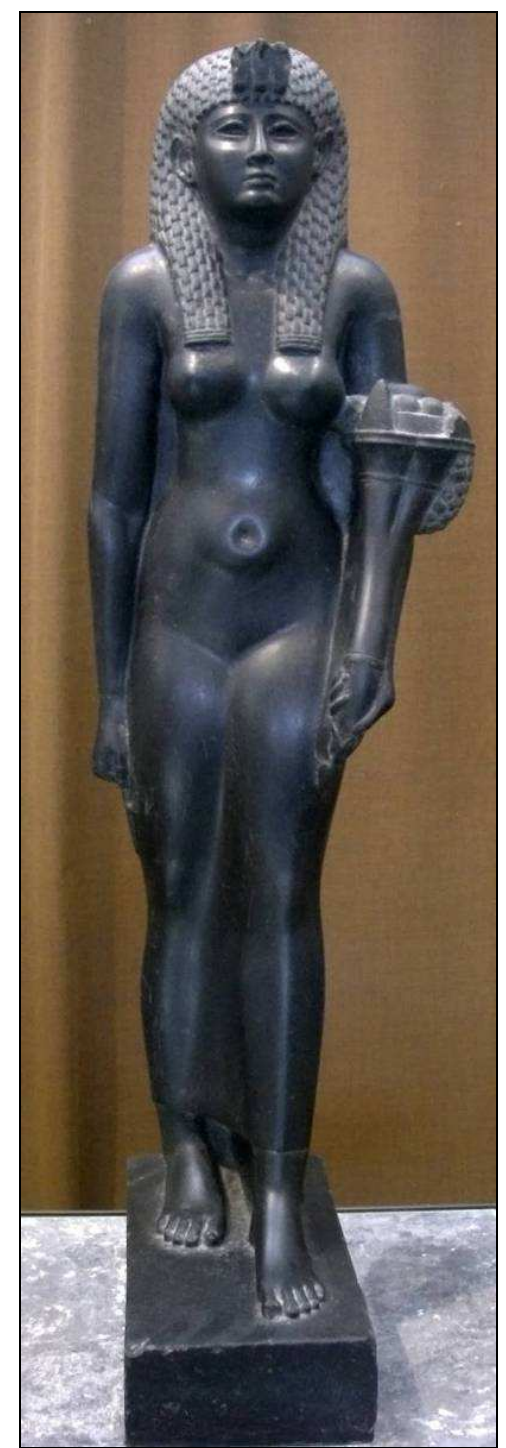

Fig. 13. Cleopatra VII?. 51-30 a.C. St. Peterburgo, Museo del Hermitage.

Imagen: Bajo licencia de Creative Commons Attribution-Share Aliked 3.0 Unported (07/09/2013). Autor: George Shuklin. 
El hieratismo propio de la estatuaria egipcia presenta un cuerpo femenino ceñido por una tela que descubre una anatomía femenina idealizada, con la pierna izquierda ligeramente adelantada y los brazos firmemente pegados al torso. Si bien el rostro evoca un cierto naturalismo, la peluca tripartita se corresponde también con las tradiciones del arte faraónico, así como el triple uraeus y el anj que porta en su mano derecha; la doble cornucopia, que sostiene sobre el brazo izquierdo, se había convertido en reverso habitual de las acuñaciones monetarias desde época de Ptolomeo II (285-246 a.C.) y fue también habitual bajo el mandato de Ptolomeo VI (180-164 y 163-145 a.C.), en las emisiones realizadas con la efigie de su esposa, Arsinoe II, como símbolo de la riqueza y fecundidad del país. A través de este atributo iconográfico, la reina no solo se asociaba con la divinidad sincrética Isitiqué, sino que, además, se vinculaba con la ya mítica feracidad del valle del Nilo, simbolizada mediante la doble cornucopia.

De hecho, esta efigie del Museo del Hermitage ha sido considerada también como una imagen de Arsinoe II, aunque el triple uraeus sugiere, según los últimos estudios, que se trata de una efigie de Cleopatra VII, pues ésta mantuvo en sus acuñaciones la doble cornucopia como reverso ${ }^{36}$. En el ejemplo mostrado de la emisión de octodracmas de Arsinoe II (Fig. 14) puede apreciarse el bello retrato de la reina, velada y con diadema, mientras el reverso muestra una doble cornucopia de la que penden sendos racimos de uvas y junto a la que puede leerse la leyenda AP $\Sigma I N O H ~ \Phi I \Lambda A \triangle E \Lambda \Phi O Y^{37}$.

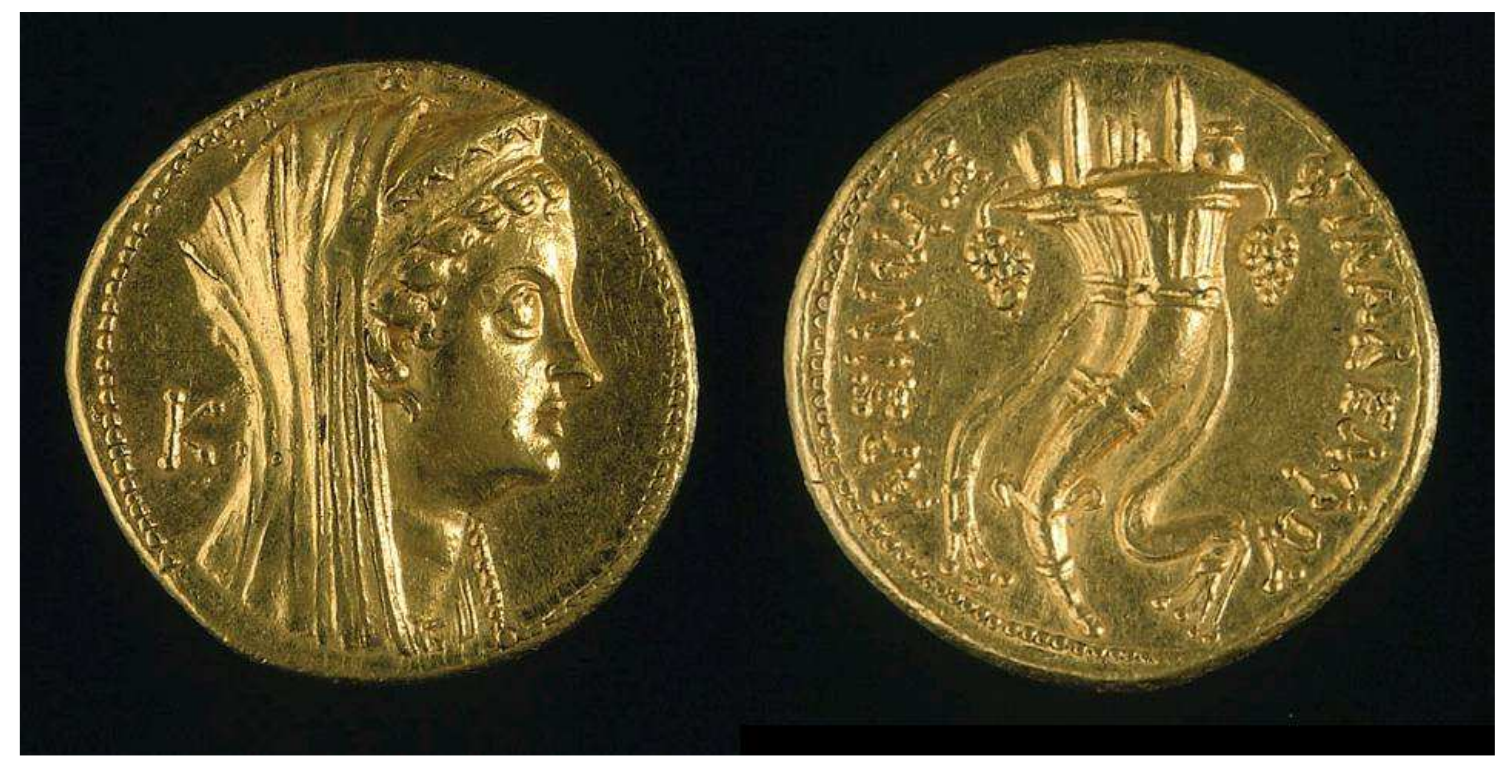

Fig. 14. Octodracma. Arsinoe II. 180-116 a.C. Hildesheim, Pelizaeus Museum. Imagen: The Global Egyptian Museum - http://www.globalegyptianmuseum.org (07/10/2013)

El tamiz helenístico que caracteriza estos prototipos egipcios tardíos, y que aún puede detectarse en la descrita efigie del Hermitage, desaparece por completo en las representaciones realizadas en los templos de nueva planta erigidos en el sur del

\footnotetext{
${ }^{36}$ S. WALKER y P. HIGGS. 2001: 160-161, catálogo no 160.

${ }^{37}$ The Global Egyptian Museum, http://www.globalegyptianmuseum.org/record.aspx?id=11502. (07/10/13). Ficha elaborada por Christian Bayer, Matthias Seidel, Heike Ständer y Bettina Schmitz.
} 
país, donde el afán de legitimación ptolemaico, gracias a la concepción egipcia de la realeza divina, se manifiesta con mayor claridad. Estos santuarios de nueva planta, ubicados en el Alto Egipto y estrechamente vinculados a la estética egipcia tradicional, sirvieron, por tanto, a los monarcas ptolemaicos como seña de identidad de su respeto por la ancestral cultura egipcia y, al mismo tiempo, fueron empleados como soporte de la legitimación de la nueva dinastía. En el centro y sur del país, donde la población autóctona continuaba fiel a sus creencias religiosas y a sus costumbres, la presencia de los monarcas ptolemaicos se ajustó escrupulosamente a los parámetros del arte egipcio. Particularmente significativa en este sentido es la estela procedente de El Fayum, que muestra una escena de ofrenda ante Isis (Fig. 15). Bajo las alas protectoras del disco alado que corona la estela, la diosa, entronizada y tocada con la corona hathórica, amamanta a Harpócrates; frente a ella, se disponen una pequeña mesa de ofrendas y un faraón sosteniendo dos vasos globulares.

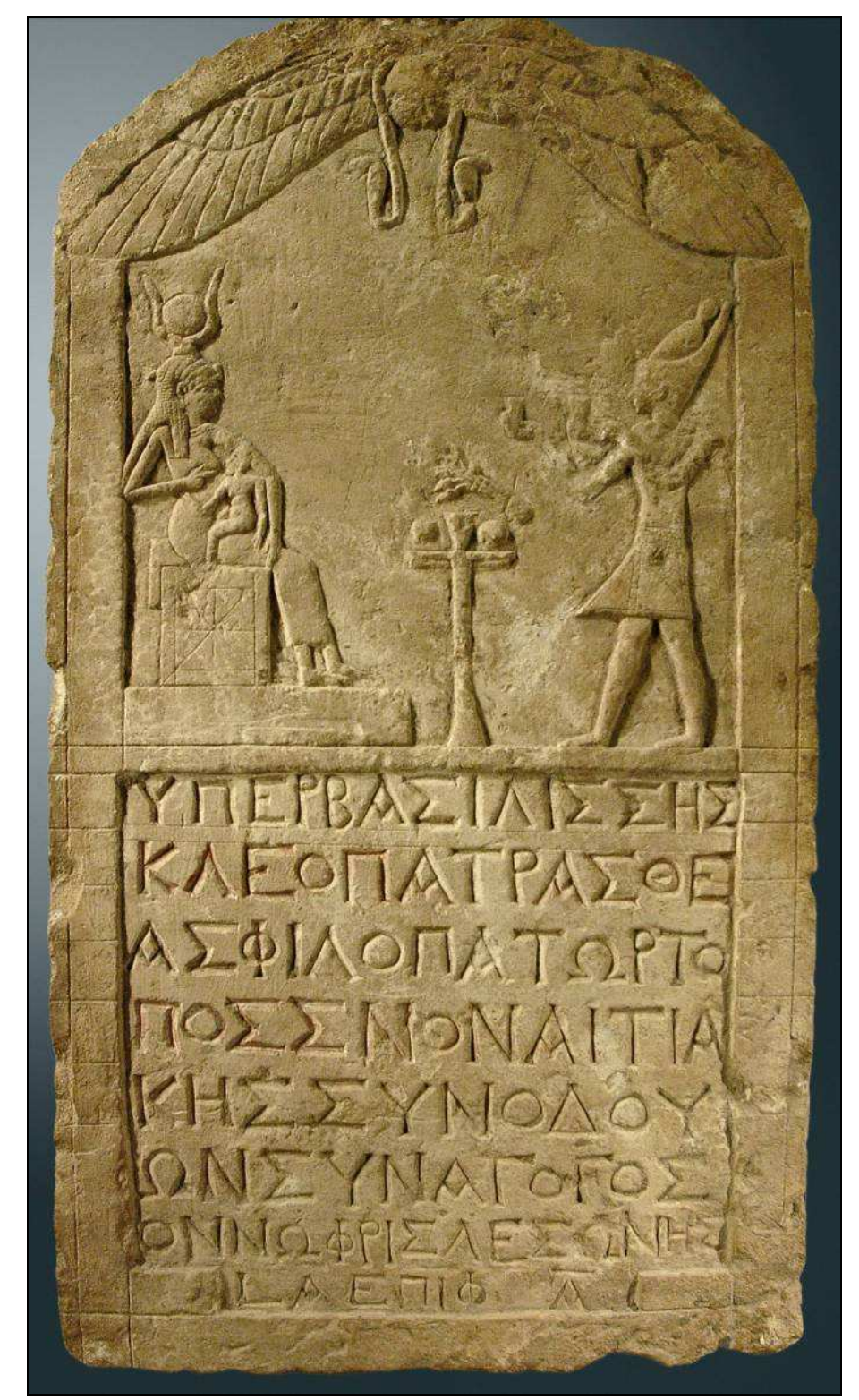

Fig. 15. Estela. Ca. 51 a.C.?. París, Museo del Louvre.

Imagen: Bajo licencia de Creative Commons Attribution-Share Aliked 3.0 Unported (07/10/2013). Autor: Jastrow (2006) 
La inscripción indica que la estela fue consagrada por un devoto de Isis, administrador del templo de la diosa en El Fayum; en la segunda línea, puede

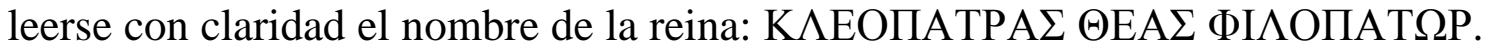
Es evidente la divinización de la soberana y, en este sentido, es significativo que la ofrenda se produzca ante la divinidad con la que se identificó Cleopatra, Isis. No obstante, aún resulta más revelador que la reina aparezca caracterizada como faraón, tocada con la doble corona que la identifica como soberano del Alto y Bajo Egipto, pero representada con indumentaria y rasgos masculinos. Se ha supuesto que puede tratarse de una estela original de Ptolomeo XII (80-58 y 5551 a.C.), adaptada bajo el reinado de Cleopatra VII, momento en el que se habría modificado la inscripción ${ }^{38}$. En cualquier caso, haya sido o no concebida bajo el mandato de la reina, esta estela muestra la intención de Cleopatra de mostrarse revestida de los símbolos de poder más tradicionales de la monarquía egipcia, personificando, si ello fuera preciso, el prototipo faraónico masculino, tal y como ya hiciera la reina Hatshepshut (ca. 1479-1458).

Cleopatra consolidó su poder en Egipto de acuerdo con los mecanismos tradicionales, no obstante, emprendió en vida la tarea de legitimar también la línea sucesoria y allanar el camino para el futuro reinado de su hijo primogénito, Ptolomeo XV Cesarión, a quien convirtió en corregente desde el año 36 a.C. Pero el joven heredero no solo podía aspirar a suceder a su madre en el trono de Egipto, sino que, además, podía reclamar en Roma los derechos inherentes a la herencia de su padre, Julio César, pues, si bien nunca llegó a producirse un reconocimiento oficial de la paternidad, César permitió que el vástago de la reina llevara su nombre:

...sed maxime Cleopatram, cum qua et conuiuia in primam lucem saepe protraxit et eadem naue thalamego paene Aethiopia tenus Aegyptum penetrauit, nisi exercitus sequi recusasset, quam denique accitam in urbem non nisi maximis honoribus praemiisque auctam remisit filiumque natum appellare nomine suo passus est. ${ }^{39}$

Pero el status del primogénito de la reina en suelo egipcio, entre la población autóctona, resultaba independiente de la paternidad de Julio César; de hecho, en el Alto Egipto, donde en mayor medida se habían conservado las creencias ancestrales, Cleopatra desarrolló un programa iconográfico destinado a la legitimación de Cesarión inspirado en las antiguas tradiciones dinásticas.

\footnotetext{
${ }^{38}$ S. WALKER y P. HiGGS. 2001: 156-7.

39 “...pero a la que más amó fue a Cleopatra, con la que frecuentemente prolongó festines hasta la nueva aurora, y en nave suntuosamente aparejada se hubiera adentrado en ella desde Egipto hasta Etiopía si el ejército no se hubiese negado a seguirle. Hízola venir a Roma, dejándola sólo marchar después de haberla colmado de dones y haber consentido en que llevase su nombre el hijo que tuvo de ella". Suetonio, Los Doce Césares, Cayo Julio César, LII, 1. Transcripción: C. SUETONIUS Tranquillus, Divus Julius, Maximilian Ihm Ed. en Perseus Digital Library: http://www.perseus.tufts.edu/hopper/ (13/10/13). Traducción según SuETONIO, Vida de los Doce Césares (2 vols.). Introducción general de Antonio Ramírez de Verger. Traducción de Rosa $\mathbf{M}^{\mathrm{a}}$ Agudo Cubas, Madrid, Gredos, 1992.
} 
En la actual localidad de Armant, Hermontis, residencia de Montu, dios de la guerra $^{40}$, existía un templo dedicado a esta deidad desde la XI Dinastía ( $c a$. 21351994 a.C.); a lo largo del Reino Nuevo y hasta época de Nectanebo II (360-342 a.C.), se sucedieron diferentes ampliaciones y remodelaciones del edificio original. Cleopatra mandó edificar en este lugar, cercano a Luxor, una Casa del Nacimiento.

Los templos egipcios se constituían como esquemas cósmicos, verdaderos microcosmos habitados por el dios y rodeados de una serie de defensas mágicas que evitaban la acción del Caos en ese mundo perfecto y dirigido por la divinidad; la idea egipcia de la creación como una especie de oasis en torno al cual se disponían las fuerzas caóticas se manifestaba en el recinto del santuario, que se correspondía con ese oasis simbólico y que era protegido mágicamente contra toda fuerza hostil ${ }^{41}$. En los templos ptolemaicos de nueva planta se respetaron las formas y estructuras autóctonas, ejecutadas por artistas locales; pero, además, se consolidó la edificación de un nuevo espacio cuya trascendencia simbólica favoreció la ansiada legitimación del poder. El mammisi ${ }^{42}$, a partir de la XXX dinastía (380-342 a.C.), fue un pequeño templo que simbolizaba la casa en la que nacían los hijos de los dioses; en este recinto se celebraba, anualmente, tal acontecimiento y su correspondiente culto sagrado. En época ptolemaica, el mammisi se concibió como un templete independiente ${ }^{43}$ imprescindible en el recinto de los santuarios. Isis, como madre del soberano encarnado en HorusHarpócrates, gozó de especial veneración y, por ello, en este espacio sagrado fue habitual la presencia de la diosa como madre del faraón infante, frecuentemente, representada como Isis Lactans, en el acto preciso de amamantar al vástago divino, heredero del trono. Es esta la iconografía de la diosa que aparece precisamente en la estela de El Fayum ya comentada (v. supra).

Cleopatra no fue ajena a este nuevo mecanismo de legitimación y edificó en Hermontis este templete donde, además de las tradicionales imágenes de la maternidad de Isis-Hathor, se hizo representar a sí misma en el momento mismo del nacimiento de Cesarión (Fig. 16). Este templo fue destruido por el Khedive Ismael para reutilizar la piedra y, actualmente, puede ser estudiado a través de las fotografías que realizara Francis Frith en $1857^{44}$. En la imagen que representaba el parto, Cleopatra aparecía arrodillada, con los brazos alzados y atendida por dos comadronas, una de las cuales sostenía ya en sus brazos a un crecido Cesarión cuya imagen había sufrido, ya en el momento de su destrucción, la damnatio memoriae.

\footnotetext{
${ }^{40}$ E. CASTEL. 2001: 272-273.

${ }^{41}$ Véase al respecto M.A. ARroYo, 2009, «Aspectos iconográficos de la magia en el antiguo Egipto: Imagen y palabra», Akros. Revista del Museo de Melilla, nº 8 (2009): 63-72.

${ }^{42}$ El término copto ma-m-misi fue acuñado, para definir estos edificios, por el francés Jean François Champollion, si bien su nombre egipcio fue pr-mswt, literalmente, Casa del Nacimiento. A. SÁNCHEZ, Diccionario de Jeroglíficos Egipcios, Madrid, Alderabán, 2000, p. 179.

${ }^{43}$ Está documentado un mammisi adosado en el templo de Hathor en Deir-el-Medina, así como en el templo de Debod, actualmente en Madrid. E. CASTEL. 1999: 93.
}

${ }^{44}$ S. WALKER y P. HIGGS. 2001: 136. 


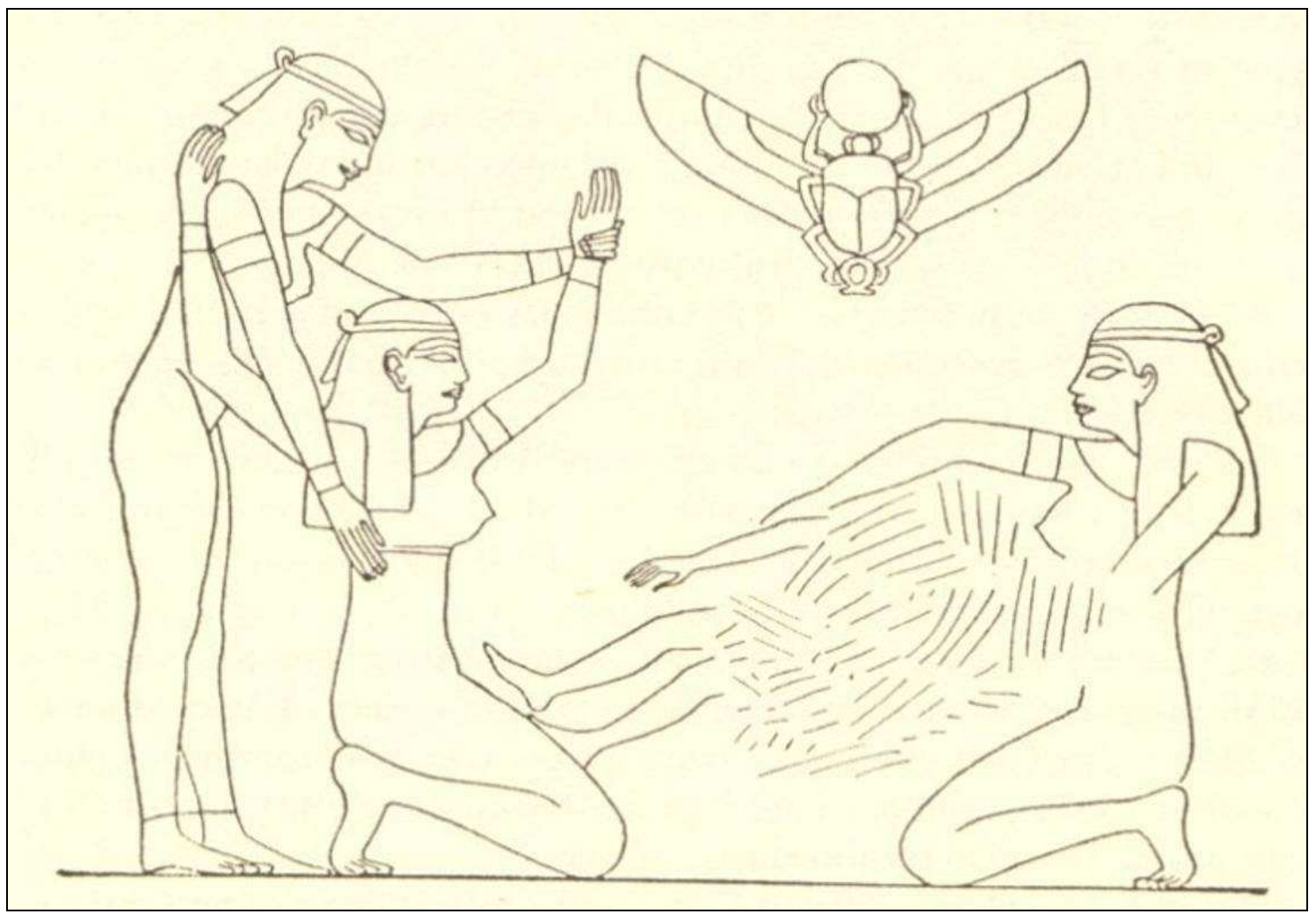

Fig. 16. Nacimiento de Cesarión. Mammisi del templo de Hermontis. S. I a.C.

Imagen: B. DE RACHEWILTZ y A.M. PARTINI, Roma Egizia. Culti, templi e divinitá egizie nella Roma Imperiale, Roma, Mediterranee, 1999, p. 30.

En Egipto, la parturienta daba a luz sentada sobre un taburete de nacimiento, dispuesto con un orificio que permitía la extracción del neonato, o bien sobre ladrillos rituales ${ }^{45}$. En este relieve de Hermontis, sin embargo, Cleopatra se muestra en una postura incompatible con el parto, pero que evoca, no obstante, el determinativo empleado en la escritura jeroglífica para expresar todos aquellos conceptos relacionados con el alumbramiento (Fig. 17). Este determinativo muestra a una mujer arrodillada y cubierta con un manto, similar a la efigie que caracteriza a la mujer de manera genérica, pero, para simbolizar el nacimiento, se añade en la parte inferior a un bebé que está siendo alumbrado ${ }^{46}$.

La escena de Hermontis se completa con un escarabeo alado que sostiene un disco solar y subraya la divinidad del neonato; al igual que la estampa descrita, el mammisi levantado por Cleopatra a pocos kilómetros del que fuera núcleo religioso del Egipto dinástico estuvo destinado, principalmente, no a la legitimación de su poder como reina en solitario de Egipto, sino a la consolidación de la sucesión de su hijo.

\footnotetext{
${ }^{45}$ A. RAMOS y D. MATA, «Gestación y nacimiento en el Antiguo Egipto», Revista de Obstetricia y Ginecología de Venezuela, v. 62, n. 2, año 2002, p. 142.

${ }^{46}$ Se puede hablar, en este caso, de una contaminación iconográfica de la escritura en la iconografía del mammisi de Hermontis. El determinativo es el símbolo B3 de Sir Alan Gardiner. A. GARDINER, Egyptian Grammar, Oxford, University Printing House, 1988 (3 ${ }^{a}$ ed. revisada). El símbolo era utilizado para escribir términos como "parir", msi, o "parto", mswt. A. SÁNCHEZ. 2000: 218-219.
} 


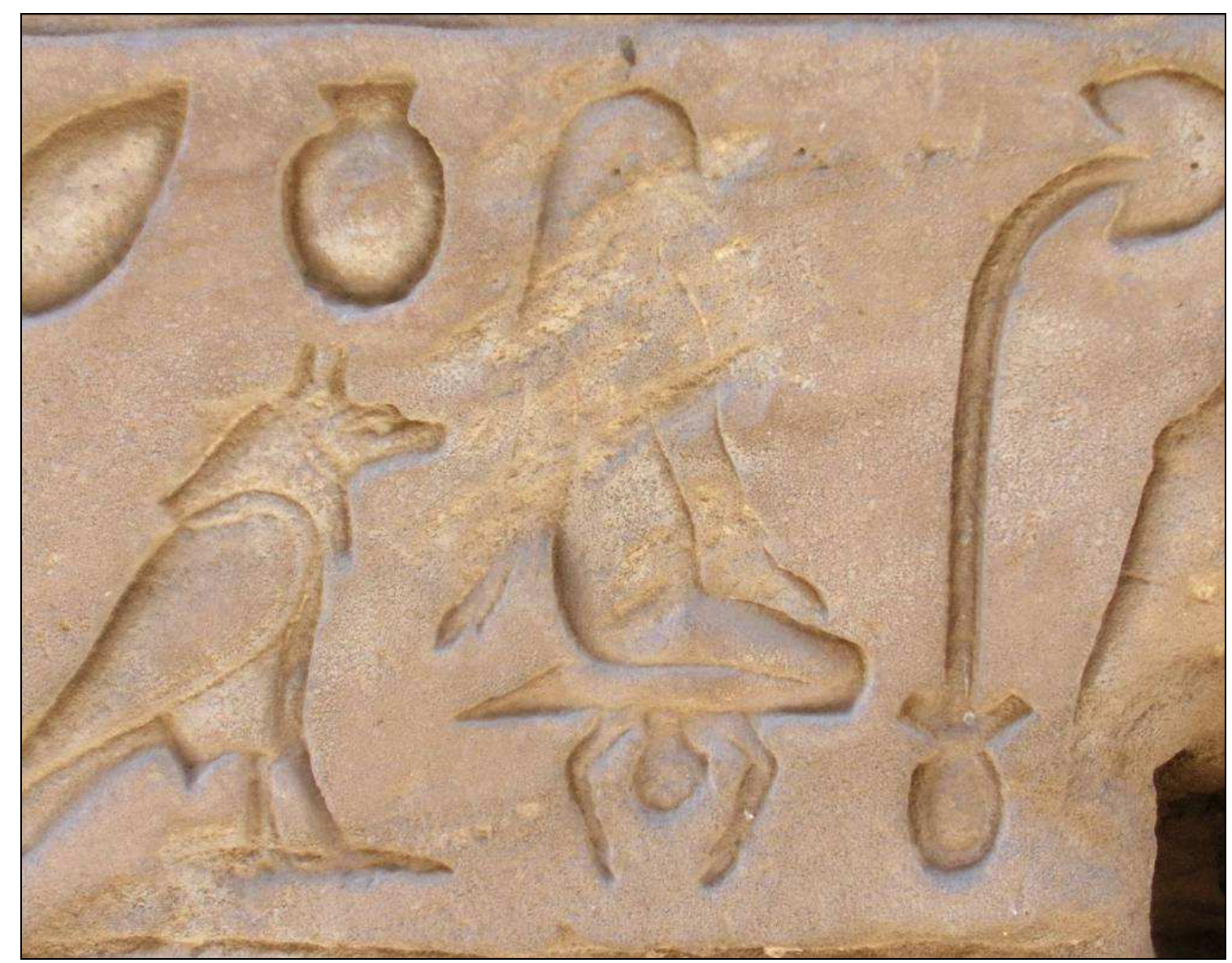

Fig. 17. Detalle de escritura jeroglífica monumental. Corredor del templo de Horus en Edfú. Época greco-romana (332 a.C. -313 d.C.). Fotografía: A. Arroyo (2005)

La política ptolemaica que, como ya se ha comentado, se caracterizó por un profundo respeto de las tradiciones religiosas y artísticas del antiguo Egipto, se pudo apreciar no tanto en la ciudad de Alejandría, abierta al Mediterráneo y controlada por la oligarquía helena, como en estos templos de nueva planta edificados en el sur del país. En el Alto Egipto, la población autóctona siguió fiel a las costumbres ancestrales y los nuevos monarcas se esforzaron por edificar sus templos de acuerdo con las formas arquitectónicas enraizadas en el interior del país, muy alejado de las influencias helenas de la costa mediterránea. En estos nuevos santuarios, en los que se incluyeron los mammisi que subrayaban la divinidad del poder político, los soberanos macedonios se hicieron representar también de acuerdo con los parámetros del arte egipcio más tradicional. En el templo de la diosa Hathor en Denderah puede contemplarse un relieve monumental que muestra a la reina Cleopatra acompañada de Cesarión en el acto de realizar una ofrenda a los dioses (Fig. 18). 


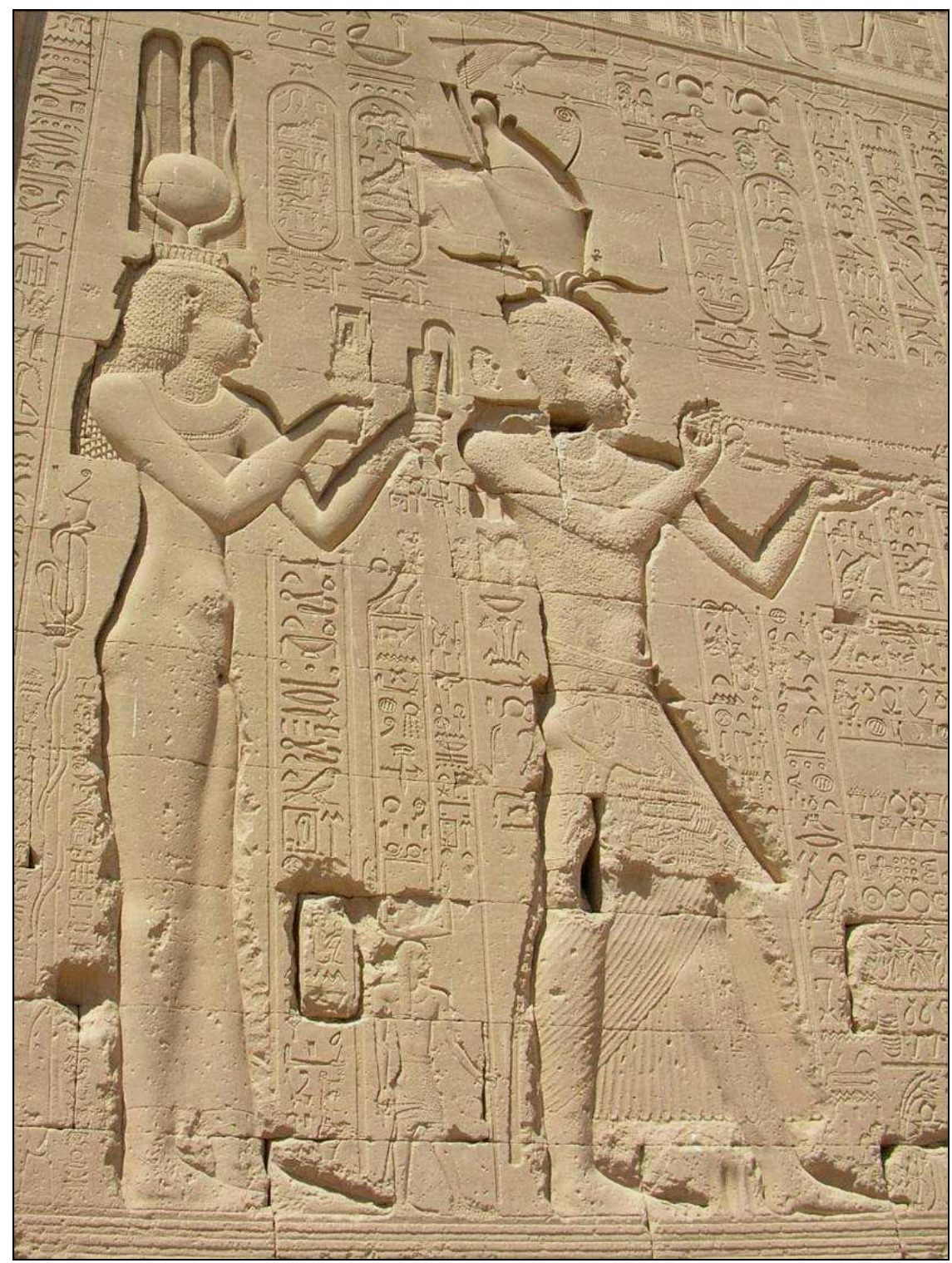

Fig. 18. Cleopatra y Cesarión. Templo ptolemaico de Hathor en Denderah. Época greco-romana (332 a.C. -313 d.C.). Fotografía: A. Arroyo (2005)

La reina se sitúa a espaldas de su hijo mientras el joven Cesarión porta la doble corona sobre su cabeza; indudablemente, la carga de legitimación recae sobre la figura del joven hijo de César, que es quien aparece tocado con la tiara que lo caracteriza como soberano de las Dos Tierras, Alto y Bajo Egipto. Asimismo, los cuernos de Amón en la base de esta corona lo vinculan con la divinidad legitimadora por excelencia en el antiguo Egipto, estrechamente vinculada también, como ya se ha visto, con el joven Alejandro Magno. La divinización de su madre, la reina Cleopatra, ataviada como la diosa Isis, con el tocado hathórico y las plumas de halcón, sirve en este caso para subrayar la legitimidad de su hijo; la presencia de Isis y la difusión y promoción de su culto, como ya se ha comentado, fue aprovechada en época ptolemaica para destacar la divinidad del faraón, encarnación de Horus, y su legitimidad como heredero del trono de Osiris. Por otra parte, las plumas de halcón constituyen una nueva alusión al vínculo con Amón esgrimido por la dinastía ptolemaica como herederos de Alejandro. Así pues, si bien Cleopatra mantiene su propia 
divinización en relación con la esposa de Osiris, en compañía de su hijo, esta imagen divinizada de la reina sirve también como refuerzo de la divinidad y legitimidad de su primogénito.

La sucesión de Cleopatra estuvo, por tanto, perfectamente orquestada por ella misma, no obstante, Octavio Augusto no toleró la independencia de Egipto. Su respeto por los esposos muertos, Cleopatra y Marco Antonio, e, incluso, su afán por educar a los hijos de este último en Roma, no se hizo patente en relación con Cesarión pues la figura del joven hijo de César se perfilaba demasiado ambiciosa, no solo por su legitimidad para el acceso al trono de Egipto, sino por su legitimidad para reclamar un puesto en la futura Roma imperial como heredero de César, papel que Augusto se había reservado para sí mismo:

...ambobus communem sepulturae honorem tribuit ac tumulum ab ipsis incohatum perfici iussit [...] item Caesarionem, quem ex Caesare patre Cleopatra concepisse praedicabat, retractum e fuga supplicio adfecit. reliquos Antonii reginaeque communes liberos non secus ac necessitudine iunctos sibi et conseruauit et mox pro condicione cuiusque sustinuit ac fouit. ${ }^{47}$

\subsection{Cleopatra en Roma.}

Puede deducirse del anhelo de Cleopatra por legitimar a su hijo en el trono que de su sucesión dependía no solo la continuidad dinástica, sino también la independencia de Egipto frente al incipiente Imperio Romano, cuya dominación temió y trató de evitar la reina durante todo su mandato, buscando una relación de igualdad, y no de sumisión frente a la potencia expansionista. A pesar del asesinato de Julio César, padre reconocido de Cesarión, tanto la pública repulsa del crimen como la constante reivindicación de su figura en boca de sus herederos políticos, Marco Antonio y Octavio Augusto, fortalecían la imagen de Cesarión como heredero del trono egipcio, pues aunaba en su persona la mítica herencia ptolemaica de Alejandro y el legado de César.

El afán de Cleopatra de convertir a su primogénito en heredero de uno de los grandes hombres de la República, destinado, además, a reinar en un Egipto soberano, como es sabido, se malogró después de la batalla de Actium (31 a.C.). No obstante, cabe analizar, desde un punto de vista iconográfico, la imagen que Cleopatra se propuso mostrar de sí misma en Roma. A pesar de que, al igual que en el entorno helenístico, no se conservan retratos que puedan ser atribuidos a

\footnotetext{
47 "Concedió a los dos esposos que reposaran en sepultura común, y ordenó que se concluyese la tumba que ellos mismos habían comenzado a construir. [...] Cesarión, que Cleopatra decía haber tenido de César, fue alcanzado mientras intentaba huir y entregado al suplicio. En cuanto a los otros hijos de Antonio y de la reina, los consideró como miembros de su familia, los educó y aseguró su posición en proporción a su nacimiento". Suetonio, Los Doce Césares, 'Octavio Augusto', XVII, 45. Transcripción: Suetonius Tranquillus, Divus Augustus, Maximilian Ihm Ed. en Perseus Digital Library: http://www. perseus.tufts.edu/hopper (15/10/13). Traducción según SUETONIO, Vida de los Doce Césares (2 vols.). Introducción general de Antonio Ramírez de Verger. Traducción de Rosa Ma Agudo Cubas, Madrid, Gredos, 1992.
} 
Cleopatra con total certeza, las fuentes dan una idea certera de cómo se concibió a la reina egipcia en la capital del naciente Imperio Romano:

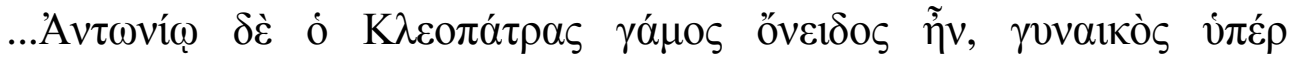

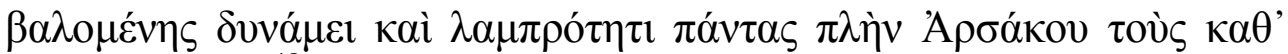
$\alpha$ vì่̀v $\beta \alpha \sigma 1 \lambda \varepsilon \tilde{\iota} \varsigma^{48}$

La visión de Plutarco en el siglo I d.C. describe a una mujer que aventajaba "en poder y esplendor a todos los reyes de su tiempo", imagen que ha perdurado, incluso, hasta nuestros días; el aura de poder que emanó su figura durante su breve estancia en Roma pervive en las fuentes a pesar del rechazo que su prepotencia despertó en los sectores más conservadores de la sociedad latina. En el ámbito de la iconografía, el poder y el esplendor se transmitieron, sin duda, a través de los símbolos de divinización que el protocolo real egipcio había consolidado a lo largo de su dilatada historia y que la dinastía ptolemaica, tal y como ya se ha destacado, continuó utilizando y desarrollando.

Son muchas y muy diversas las obras en las que se ha creído vislumbrar el rostro de la reina. Entre las posibles imágenes de Cleopatra halladas en territorio latino destaca, por su profusa iconografía, la denominada Copa de África, perteneciente al Tesoro de Boscoreale (Fig. 19) ${ }^{49}$.

Esta magnífica copa muestra una imagen Panthea que aúna los atributos y capacidades de diferentes divinidades; está relacionada con la diosa Selene en tanto uno de los símbolos más significativos que porta la joven representada es el creciente lunar, que destaca por encima de la cornucopia. En el centro del vaso, una bella mujer de encrespados cabellos se rodea de una gran profusión de símbolos iconográficos, que hacen referencia a muy diversas deidades del panteón greco-latino y, en particular, a la diosa Isis.

La joven cubre su cabeza con una piel de elefante a modo de tocado; sobre su frente se alza la trompa del animal mientras la piel cae por detrás de su cabeza y, a ambos lados del cuello, se aprecian las características orejas del animal. El tocado, que ya se ha comentado en las acuñaciones numismáticas de Ptolomeo I cubriendo la testa de Alejandro (v. supra), fue considerado un símbolo de África o, en su defecto, de una de las más célebres metrópolis del continente,

\footnotetext{
48 “...y en Antonio se miraba como cosa de menos valer el matrimonio con Cleopatra, mujer que sobrepujaba en poder y en esplendor a todos los reyes de su tiempo, excepto Arsaces". Plutarco, Vidas Paralelas, 'Comparación de Demetrio y Antonio', I, 3. Transcripción: PluTARCH, Plutarch's Lives, with an English Translation by Bernadotte Perrin, Cambridge, Harvard University Press, en Perseus Digital Library: http://www.perseus.tufts.edu/hopper (15/10/13). Traducción según Plutarco. Vidas paralelas. Demetrio-Antonio. Introducción, traducción y notas de Juan Francisco Martos Montiel, Madrid, Alianza, 2007.

${ }^{49}$ El denominado Tesoro de Boscoreale, hallado en las excavaciones de 1895, consta de ciento nueve piezas, todas ellas de plata, entre las que se encuentran piezas de vajilla, enseres de tocador y joyas. Todo ello fue ocultado por el propietario de una villa ubicada en las faldas del Vesubio, con anterioridad a la terrible tragedia del año 79 d.C. La valía de este tesoro radica, no sólo en la riqueza de las numerosas piezas de plata sino, especialmente, en la elaborada y particular iconografía de algunas de estas creaciones que representan un punto culminante de la orfebrería romana.
} 
Alejandría. No obstante este peculiar tocado, de su cabeza surgen dos pequeños cuernos bovinos, que solo pueden hacer referencia a Ío, la doncella argiva, amada de Zeus, que fue convertida en vaca por el Crónida para eludir los celos de su esposa; Hera hizo que Argos custodiara a la ternera hasta que el dios Hermes la liberó y, tras muchas vicisitudes, arribó a Egipto y fue asimilada con la diosa Isis. A pesar de recuperar su figura humana, Ío conservó los cuernos de vaca, relacionados entonces con el tocado hathórico que lucía Isis ${ }^{50}$. La mujer representada en esta copa puede, por tanto, personificar a esta diosa; la piel del elefante, símbolo de África, es apropiada para una deidad egipcia y, por otra parte, la trompa del animal recuerda vagamente el tradicional uraeus que coronaba la diadema real; de hecho, sujeta también con su mano diestra a este animal heráldico, la cobra, como indiscutible alusión a Egipto.

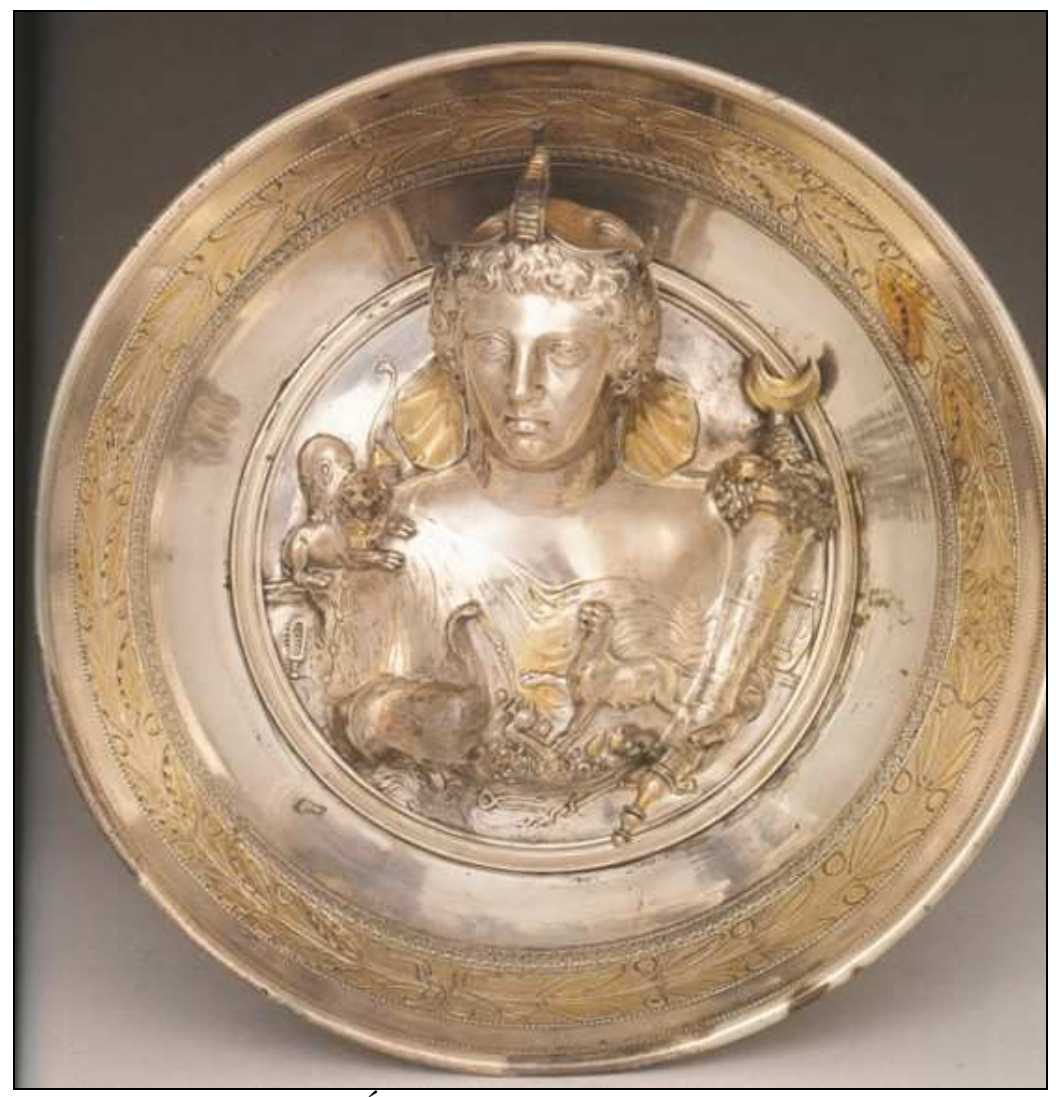

Fig. 19. Copa de África. S. I d.C. París, Museo del Louvre Imagen: S. WALKER y P. HIGGS. 2001: 312.

En su mano izquierda, porta una elaborada cornucopia, habitual en las acuñaciones alejandrinas (v. supra); en el cuerpo de este cuerno de la abundancia, puede apreciarse la figura de un águila y el busto de Helios, hermano de Selene, cubierto con una túnica y coronada su cabeza con los rayos solares. Según algunos autores ${ }^{51}$, esta imagen sugiere la representación en esta copa de los hijos de Cleopatra VII y Marco Antonio: Cleopatra Selene, personificando a la diosa, y su hermano Alejandro Helios, en el cuerpo de la cornucopia.

\footnotetext{
${ }^{50}$ P. GRIMAL. 1981: 289-290. Véase también el relato de Ovidio (Met. I, 585 y ss.).

${ }^{51}$ S. WALKER y P. HIGGS. 2001: 312
} 
Tras la batalla de Actium, los hijos de Cleopatra VII y Marco Antonio fueron llevados a Roma, donde Augusto confió su educación a su hermana Octavia. Posteriormente, tras la muerte de Alejandro Helios, Cleopatra Selene se casó, por deseo expreso de Augusto, con Juba II de Numidia; así pues, según la hipótesis apuntada, el tocado de piel de elefante y la cornucopia pueden hacer referencia a África en relación con el propio Juba. En el mismo sentido, se ha supuesto que pueda tratarse de un retrato de la propia Cleopatra VII divinizada. ${ }^{52}$

Además de los atributos principales ya descritos de esta divinidad Panthea, pueden apreciarse otros muchos ${ }^{53}$. La concepción Panthea de esta Isis responde al epíteto de Diosa de los Mil Nombres ${ }^{54}$, que, debido a las múltiples identificaciones con otras divinidades, adquirió la diosa egipcia en época imperial; no obstante, el destacado creciente lunar sugiere una particular asimilación con Selene. Con respecto a esta magnífica pieza, la posible identificación con Cleopatra VII, con su hija Cleopatra Selene, o bien la hipotética personificación de la ciudad de Alejandría, alude a la honda complejidad que encerró el sincretismo greco-egipcio.

A la derrota definitiva de Cleopatra VII se sucedieron una serie de represiones del culto isiaco, dirigidas principalmente por Augusto y por Tiberio; no obstante, con posterioridad, la incorporación de Egipto como provincia del Imperio no hizo sino acrecentar el éxito de los cultos egiptizantes en el seno de la sociedad romana. Augusto apoyó especialmente los cultos de Venux Genetrix, Divus Julius, Mars Ultor y Apolo Palatino. Los tres primeros sentaron las bases de la divinización del emperador, inspirada en las ideas tradicionales del genius y el numen; por un lado, Augusto enfatizaba la divinidad de su padre adoptivo y, por otro, destacaba la genealogía divina de los Julios entroncada con Venus y Marte,

\footnotetext{
${ }^{52}$ Véase al respecto la página oficial del Museo del Louvre acerca del Tesoro de Boscoreale y el comentario de Astier Marie-Bénédicte: http://www.louvre.fr/en/oeuvre-notices/boscoreale-treasure $(16 / 10 / 13)$.

${ }^{53}$ Junto a la cornucopia, la lira de Apolo; sobre el hombro derecho de la diosa, se distinguen la clava de Hércules, el arco de la diosa Ártemis y un león; junto a su mano derecha, se ha representado un pequeño sistro, instrumento ritual del culto isiaco, un delfín que puede aludir a Posidón, un pavo real, animal asociado a la diosa Hera, una espiga que puede hacer referencia a Deméter, y una granada que evoca la catábasis de Perséfone; en el extremo inferior de la copa, pueden verse, también, las tenazas de Hefesto y la vara de Esculapio, así como una bella figura de pantera. Existen, por tanto, referencias a diosas con las que se identificó la egipcia Isis: la propia Selene, Fortuna, Ártemis, Hera, Deméter, Perséfone e, incluso, se podría relacionar al león y la pantera con Hécate, quien podía transformarse en diversos animales (P. GRIMAL. 1981: 225), aunque también puede ser una velada alusión a Dioniso. Estas múltiples asimilaciones forman parte del carácter de Panthea de la diosa Isis, quien llegó a asimilarse también con dioses como Asclepio, por sus capacidades mágico-curativas. Llama, no obstante, la atención la representación de la clava hercúlea, así como la referencia a dioses como Apolo, Posidón o Hefesto; sin entrar en sutiles vínculos de la diosa con la navegación u otras atribuciones, podría relacionarse a estas deidades olímpicas con el sentido apotropaico de la propia pieza, que aúna la protección de todos los dioses aludidos en ella.

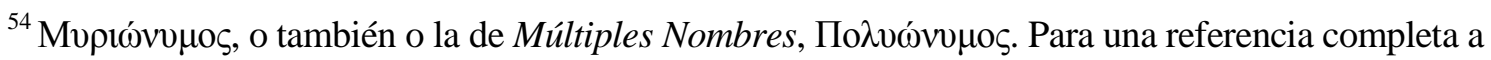
las identificaciones de Isis con otras diosas, así como a los diferentes epítetos aplicados a la diosa en la zona de Campania, véase V. TRAN TAM TINH, Le Culte des divinités orientales en Campanie en dehors de Pompéi, de Stabies et d'Herculanum, Leiden, E.J. Brill, 1972, p. 214-219 y 220-229.
} 
asociando la tradición griega de Eneas y la latina de Rómulo ${ }^{55}$. El templo de Marte fue también recuerdo de las glorias militares, y Apolo, a quien Augusto atribuyó la victoria de Actium, se consolidó como baluarte de esas victorias militares y, además, como oponente y vencedor de los cultos orientales, encarnados por Cleopatra VII Filópator.

No debe olvidarse que, en época augústea, el culto isiaco no solo era identificado como externa superstitio, sino que se rechazaba, porque la reina Cleopatra VII se había autoproclamado encarnación de la diosa. En estas circunstancias, la victoria de Actium supuso un duro revés para la implantación definitiva del culto isiaco en Roma, vinculado a la derrota y conquista del enemigo. Sin embargo, la propia dinámica del Imperio impidió el éxito de la política conservadora augústea, ya que los cultos orientales resultaban mucho más atractivos que la religiosidad tradicional. El culto isiaco, pues, afianzado en Roma a lo largo del siglo I a.C., sufrió un gran retroceso en época de Augusto; en el año 28 a.C., prohibió la colocación de altares isiacos en el pomerium y, en su ausencia, Agripa desautorizó la práctica de los ritos alejandrinos en un radio de 1500 metros alrededor de Roma ${ }^{56}$. Cabe también destacar, de nuevo, la identificación de las reinas ptolemaicas con la diosa y, particularmente, la encarnación de Isis en Cleopatra VII, paradigma, según la visión latina, de las depravadas costumbres orientales que habían corrompido a Julio César y a Marco Antonio:

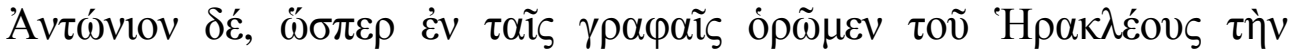

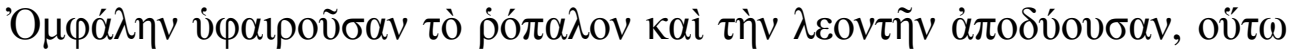

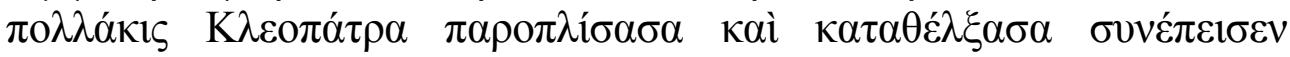

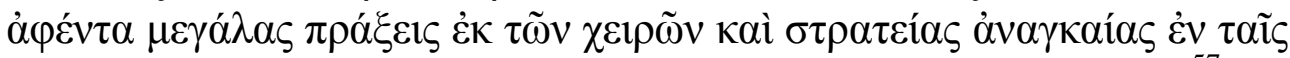

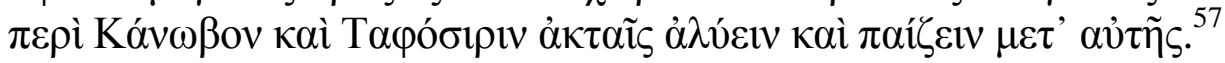

\footnotetext{
${ }^{55}$ J. BAYET, La religión romana: historia política y psicológica, París, Cristiandad, 1984, p.190191.

${ }^{56}$ Según Dion Casio (Hist. Rom. LIII, 2, 4), Augusto excluyó los cultos egipcios del pomerium. B. DE RACHEWILTZ y A.M. PARTINI, Roma Egizia. Culti, templi e divinitá egizie nella Roma Imperiale, Roma, Mediterranee, 1999, p. 32. Así también en S.B. Platner y T. ASHBY, A Topographical Dictionary of Ancient Rome, Londres, Oxford University Press, 1929, p. 283284. Pero, según Filipo Coarelli, estas prohibiciones debieron afectar tan sólo a santuarios isiacos de carácter privado. F. COARELLI, «Roma e Alessandria», p. 44. En E. LO SARDO (ed.). La Lupa e la Sfinge. Roma e l'Egitto dalla storia al mito. Catálogo de la Exposición. Roma, Museo Nazionale di Casteli Sant'Angelo (11 Iuglio - 9 novembre 2008). Milán, Electa, 2008, p.37-47.

57 “'Antonio, así como en las pinturas de Hércules vemos a Ónfala que le quita la maza y le desnuda de la piel del león, de la misma manera, desarmándole muchas veces Cleopatra y haciéndole halagos, le persuadía a desentenderse de grandes negocios y de las expediciones más precisas, para divertirse y entretenerse con ella en la ribera, junto a Canopo y Tafosiris". Plutarco, Vidas Paralelas, 'Comparación de Demetrio y Antonio', III, 3. Transcripción: PluTARCH, Plutarch's Lives, with an English Translation by Bernadotte Perrin, Cambridge, Harvard University Press, en Perseus Digital Library: http://www.perseus. tufts.edu/hopper (16/10/13). Traducción según Plutarco. Vidas paralelas. Demetrio-Antonio. Introducción, traducción y notas de Juan Francisco Martos Montiel, Madrid, Alianza, 2007.
} 
Esta presencia de Cleopatra en Roma, intitulada y revestida como una Nueva Isis, no ha dejado una huella iconográfica clara, si exceptuamos una bellísima cabeza de mármol, tocada con el tradicional plumaje de buitre que, actualmente, se conserva en Roma, expuesta en la Centrale Montemartini (Fig. 20). Fue hallada en el interior de la iglesia de San Pedro y San Marcelino, en la Via Labicana, muy cerca de donde hubo de hallarse el templo de Isis y Serapis que dio nombre a la Regio III de la ciudad. En las inmediaciones de esta iglesia, entre los años 1886-1887, fueron halladas diversas piezas relativas al culto ${ }^{58}$.
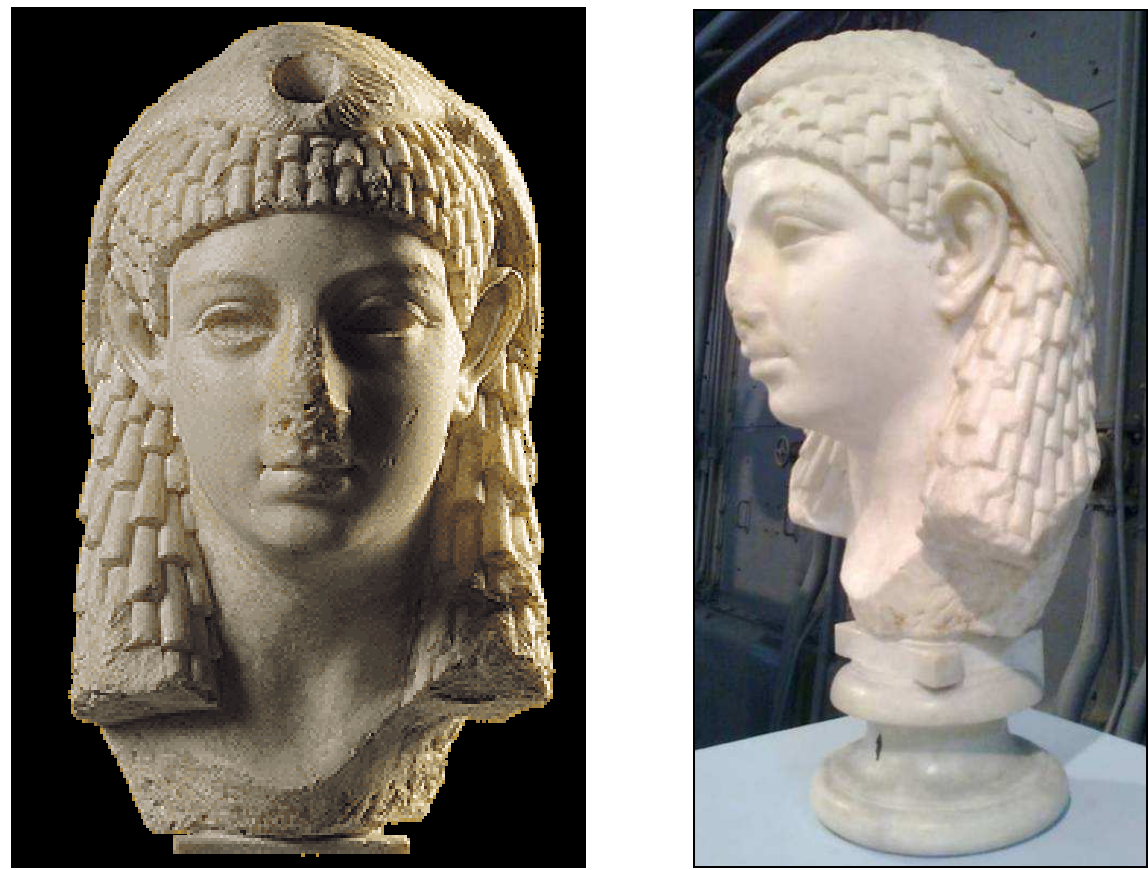

Fig. 20. Cleopatra VII ?. S. I a.C. - I d.C. Roma, Centrale Montemartini. Imagen 1: S. WALKER y P. HIGGS. 2001: 217, no 194.

Imagen 2: Claudina Romero Mayorga (2012)

Esta cabeza puede ser una imagen de culto; no obstante, algunos rasgos ya destacados de Cleopatra, como los pómulos prominentes o los labios carnosos, pueden sugerir un retrato en su personificación de la diosa. Si bien ciertos rasgos fisonómicos pueden recordar vagamente al prototipo de la reina transmitido por las monedas, el bello rostro puede atribuirse a un artista alejandrino, pues los atributos reales están perfectamente definidos. Sobre la peluca puede apreciarse el plumaje del buitre y sobre la frente el orificio destinado para la cabeza del animal; en la parte superior existe otro orificio que se ha supuesto para la colocación de un tocado hathórico ${ }^{59}$.

El plumaje del buitre era un símbolo real que puede hacer alusión a la reina y que, además, fue símbolo de la diosa Mut, ${ }^{60}$ pero, por otra parte, el buitre

\footnotetext{
${ }^{58}$ En el año 1886-87, fueron encontradas una cabeza de Júpiter Serapis, una estatua de Isis, una pequeña estatua de Anubis y otras piezas. En el 1889 salió a la luz un cippo marmóreo con una inscripción que conmemoraba la donación hecha a Isis por un liberto y procurador imperial de nombre Muciano. B. DE RACHEWILTZ y A.M. PARTINI. 1999: 83-84.
}

${ }^{59}$ S. WALKER y P. HIGGS. 2001: 217.

${ }^{60}$ E. CASTEL. 2001: 274-275. 
también fue el animal que encarnaba en Egipto la maternidad y, de hecho, era el símbolo elegido para escribir la palabra madre ${ }^{61}$; por ello, indudablemente, este emblema pudo servir como forma de subrayar la ya comentada trascendencia de la maternidad de la reina. Si bien la encarnación de Isis en las reinas ptolemaicas era una tradición (v. supra), la identificación de Cleopatra con la diosa alcanzó unas cotas de teatralidad que superaron cualquier otra referencia a esta deidad en relación con la monarquía:

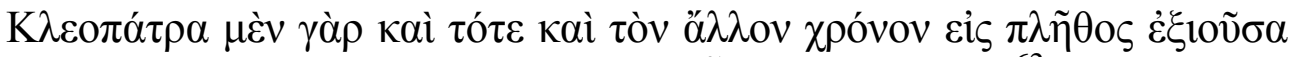

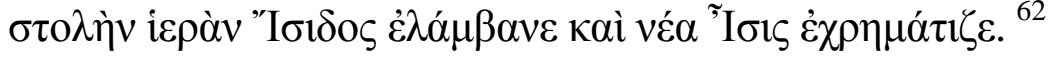

La presencia de Cleopatra en Roma supuso un duro revés para la figura de Julio César, que no reparó en atenciones con la reina egipcia. Al margen de algunas de las críticas ya reseñadas y si bien César no llegó a contraer matrimonio con la reina egipcia, sí se permitió llevar a cabo actos públicos de reconocimiento, que denotaron no solo el romance entre ambos, sino también el respeto político que el prócer romano profesó a la reina de Egipto. La legitimidad del trono que Cleopatra ocupaba fue acentuada en Egipto por la deificación de la reina, deificación que la propia Cleopatra se encargó de subrayar a través de su encarnación en la diosa Isis; pero, si bien el culto de la diosa alejandrina había cundido ya entre los ciudadanos latinos, César afianzó esa divinización de la reina también en relación con el panteón greco-romano.

Durante la permanencia de Cleopatra en Roma, César inauguró un templo dedicado a Venus Genetrix, divinidad que también fue identificada con Isis, y en el interior del santuario hizo colocar una imagen de la reina:

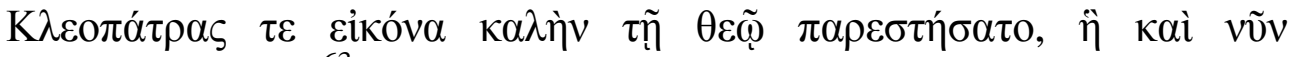

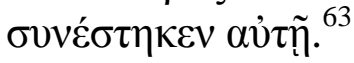

Este hecho, transmitido por las fuentes, ha generado numerosas hipótesis acerca del supuesto original y las posibles copias de la escultura que Julio César hizo erigir en el templo, y que, de acuerdo con las propias fuentes, sería un fiel retrato de la reina.

\footnotetext{
${ }^{61}$ A. SÁNCHEZ. 2000: 206.

62 "No salía en público sino con la ropa sagrada de Isis, y como una nueva Isis daba oráculos". Plutarco, Antonio, LIV, 6. Transcripción: PLUTARCH, Plutarch's Lives, with an English Translation by Bernadotte Perrin, Cambridge, Harvard University Press, en Perseus Digital Library: http://www.perseus. tufts.edu/hopper/ (22/09/13). Traducción según PLUTARCO, Vidas paralelas. Demetrio-Antonio. Introducción, traducción y notas de Juan Francisco Martos Montiel, Madrid, Alianza, 2007. También puede entenderse, simplemente, que en público la reina "actuaba" como la diosa Isis.

63 "Colocó una hermosa imagen de Cleopatra al lado de la diosa, que está ahí aún en el día de hoy". Apiano, Historia de Roma, Guerras Civiles, II, XV, 102. Transcripción: APPIAN, The Civil Wars, L. Mendelssohn Ed. en Perseus Digital Library: http://www.perseus.tufts.edu/hopper/ (18/10/13). Traducción según APIANO, Historia Romana. Vol II. Guerras Civiles (Libros I-III). Traducción y notas de Antonio Sancho Royo, Madrid, Gredos, 1985.
} 

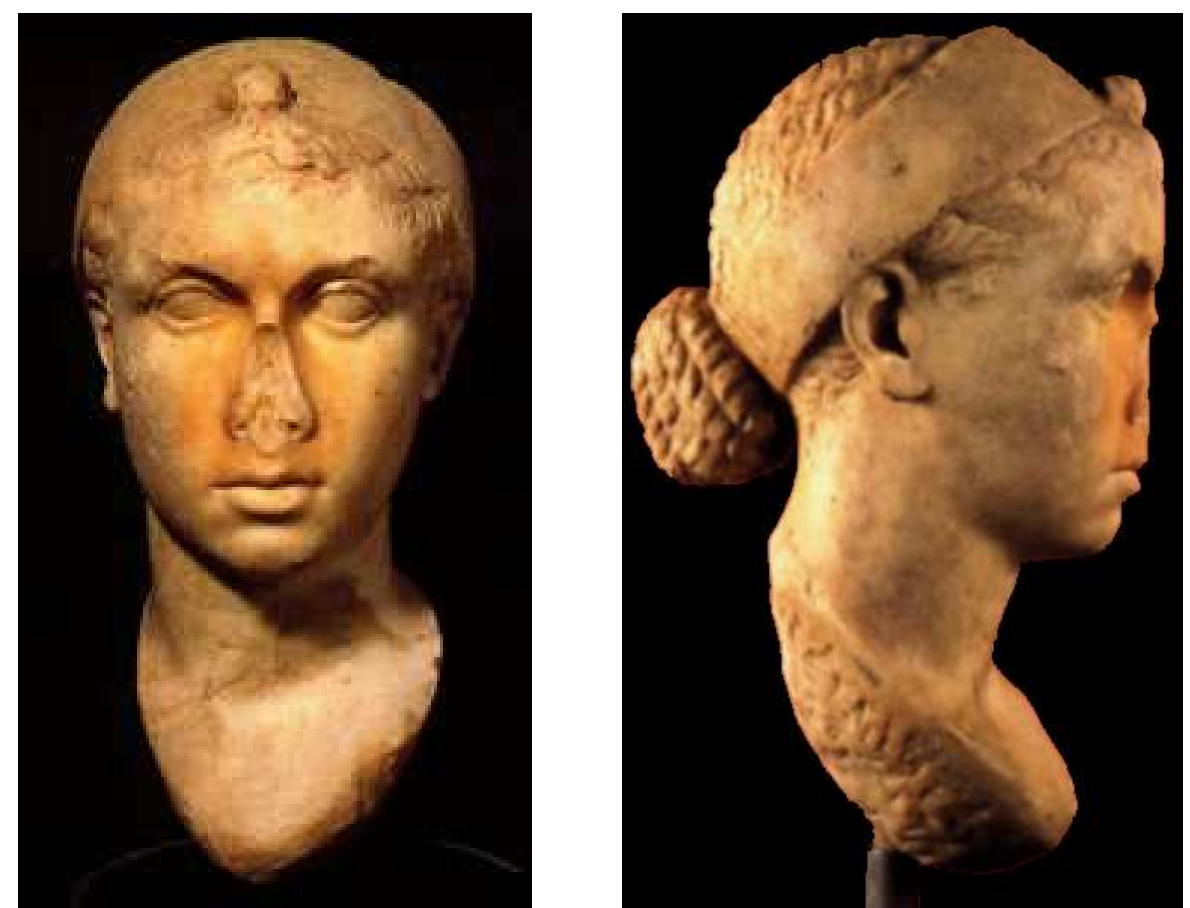

Fig. 21. Cleopatra VII?. Ca. 50-30 a.C. Vaticano, Museo Gregoriano Profano Imagen: S. WALKER y P. HIGGS. 2001: 218, nº 196

Entre estas obras puede citarse la cabeza conservada en el Museo Gregoriano y hallada en la Villa de Quintilio, en la Via Appia, que muestra a una joven tocada con una diadema (Fig. 21). Aunque ha sido identificada como una cabeza de la diosa Ceres, cubierta con una ínfula, los rasgos pueden recordar vagamente a los ya aludidos para identificar a la reina Cleopatra, y el hecho de que sobre la frente muestre una prominencia que puede sugerir la presencia de un símbolo real egipcio - un buitre o un uraeus - , hace de esta obra una de las posibles réplicas de la escultura erigida por César ${ }^{64}$. De acuerdo con las fuentes, se ha querido ver también el rostro de Cleopatra en otras esculturas asociadas con Venus y halladas en Roma.

La denominada Venus del Esquilino muestra a una mujer joven con un bello recogido en el pelo; el rostro, muy idealizado, resulta muy difícil de asociar con los rasgos conocidos de la reina (Fig. 22). No obstante, la cista con el áspid situada a sus pies ha sugerido la identificación de esta bellísima joven con una representación Isis-Venus y, por tanto, con la famosa estatua erigida por César en el templo de Venus Genetrix.

También se ha querido identificar el simbólico regalo de César a la reina con la Venus Capitolina (Fig. 23), cuyo cuerpo se inspira en el original de la Afrodita Cnidia de Praxiteles, hallada en el Viminal. Si bien el rostro denota a una mujer más madura y unos rasgos menos idealizados, tampoco puede afirmarse con certeza que se trate de la estatua dedicada en el templo de Venus por Julio César.

${ }^{64}$ Existe otra famosa cabeza, copia de ésta, conservada en el Staaliche Museum de Berlín, de procedencia desconocida y que fue adquirida por la colección Despuig en el siglo XVIII. S. WALKER y P. HIGGS. 2001: 204. 
Ma Amparo ARROYo DE LA FUENTE, Cleopatra VII Filópator y la legitimación del poder ptolemaico
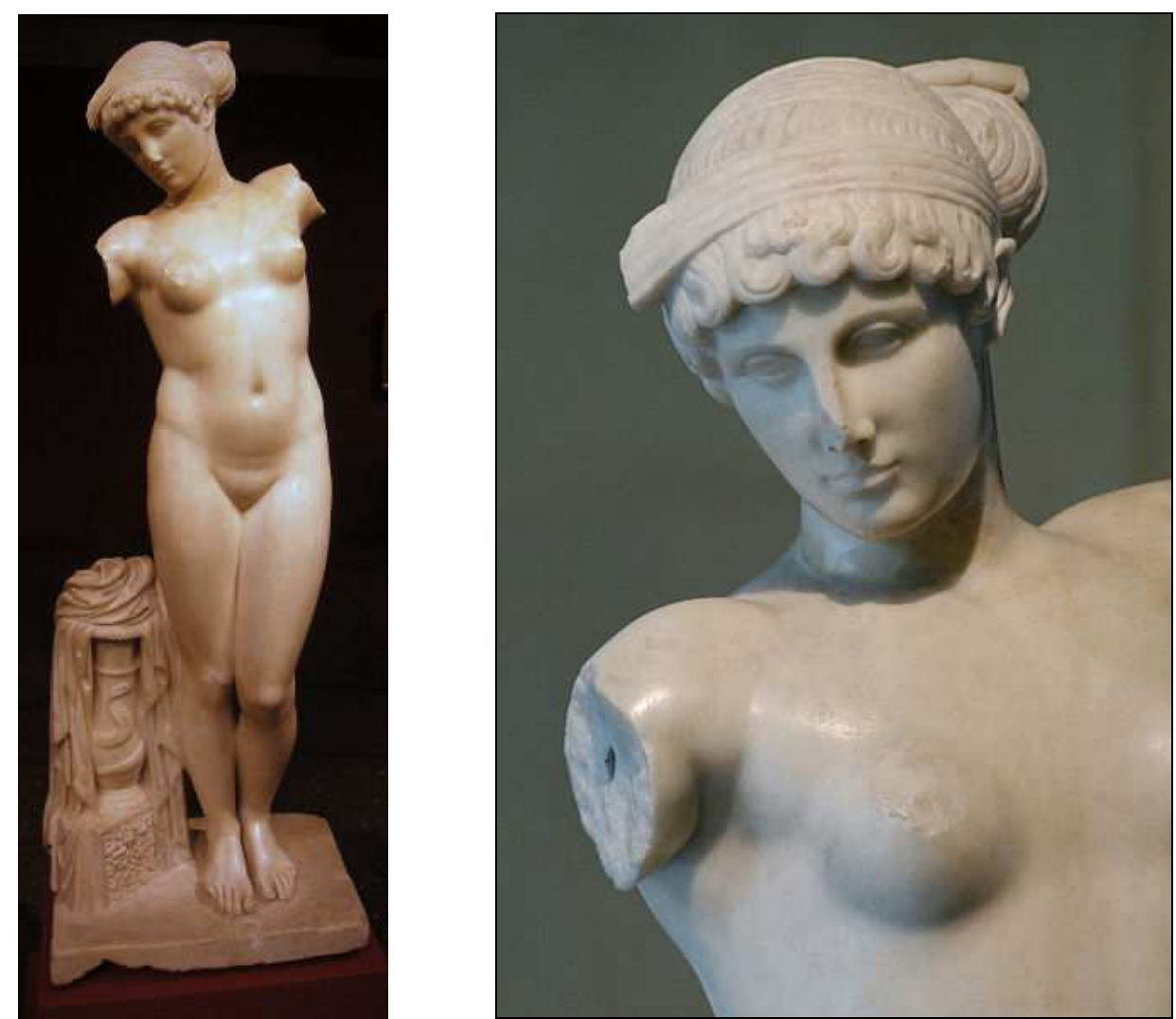

Fig. 22. Venus del Esquilino. S. I d.C. Roma, Museos Capitolinos. Imagen 1: Bajo licencia de Creative Commons Attribution-Share Aliked 3.0 (18-10-2013). Autor: didi46.

Imagen 2: Bajo licencia de Creative Commons Attribution 2.5 Generic. Autor: Marie-Lan Nguyen (2009)
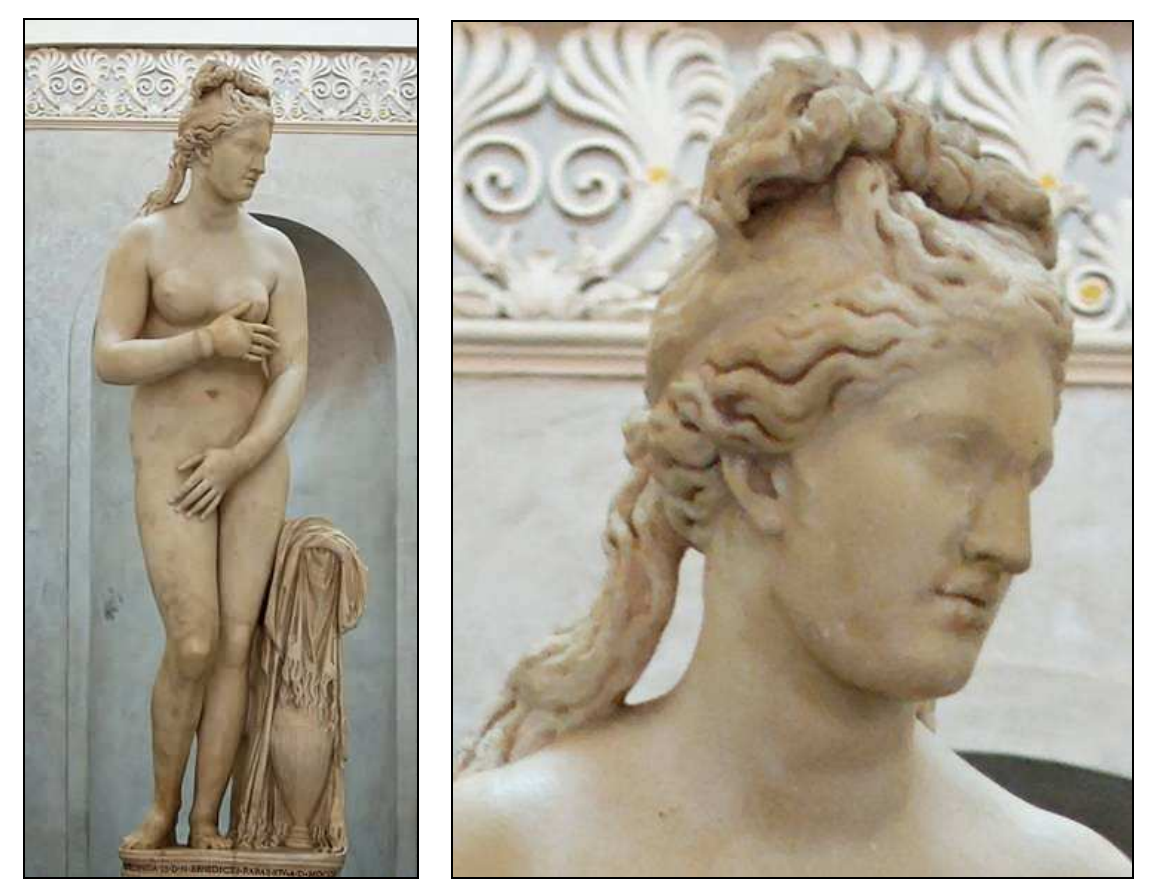

Fig. 23. Venus Capitolina. S. I d.C. (Copia neoática de un original de Praxiteles, s. IV a.C.). Roma, Museos Capitolinos.

Imagen: Bajo licencia de Creative Commons Attribution-Share Aliked 3.0 (18-10-2013). Autor: Jastrow (2006) 
La relación simbólica de la reina Cleopatra VII con el flamante templo de Venus Genetrix no solo se estableció a través del amor de César, declarado públicamente; también constituyó, en cierto sentido, una forma de subrayar la identificación de las diosas Isis y Venus, y de apoyar el culto de las divinidades alejandrinas al hilo de la presencia de la reina de Egipto en Roma. El episodio constituye, en cierto sentido, una confirmación de los esfuerzos de la reina por consolidar su deificación en apoyo de la legitimación de su poder sobre el trono de Egipto. Desde el punto de vista iconográfico, existe una estrecha relación entre la belleza idealizada y la divinidad, pues la perfección física se concibe como el sustento necesario de la divinidad; la insistente presencia de Cleopatra en Roma como reina divinizada, probablemente tuvo mucho que ver en la mítica imagen de la reina como una mujer bellísima, a pesar de las descripciones objetivas que nos han legado las fuentes (v. supra).

Las críticas de los sectores más conservadores de la sociedad romana aborrecían el lujo y las costumbres de la corte alejandrina, en cuyas redes supusieron atrapados a dos de los grandes hombres de la República, Julio César y Marco Antonio, pero, cuando incluso Octavio Augusto respetó la voluntad de los amantes de reposar juntos, Marcial ridiculizó el status real de Cleopatra:

Flentibus Heliadum ramis dum vipera repit,

Fluxit in obstantem sucina gutta feram:

Quae dum miratur pingui se rore teneri,

Concreto riguit vincta repente gelu.

Ne tibi regali placeas, Cleopatra, sepulchro,

Vipera si tumulo nobiliore iacet ${ }^{65}$.

\section{Conclusiones}

La legitimación del poder ptolemaico en Egipto se inició desde la conquista de Alejandro, pues él mismo se propuso intitularse hijo de Amón y sucesor de los faraones. A partir de entonces, con la instauración de la dinastía de la mano de Ptolomeo I, se inició la concreción de la legitimación del poder en el territorio mediante los mecanismos tradicionales de la política egipcia. Los nuevos gobernantes se hicieron representar según los parámetros del arte tradicional, asumieron los títulos propios, que se inscribieron junto a sus imágenes, y adoptaron la divinización del poder. Por otra parte, dada la estrecha relación entre el poder y la religión, los nuevos mandatarios fijaron la imagen de sus dioses tutelares mediante divinidades sincréticas que se ajustaban también a la mentalidad helena, como Serapis o Isitiqué.

\footnotetext{
65 "Reptando una víbora por las ramas llorosas de las Helíades, / una gota de ámbar se escurrió sobre la bicha completamente de frente. / Ella, mientras se admira de verse detenida por el viscoso rocío, / quedó rígida aprisionada de pronto por un hielo macizo. / No te enorgullezcas, Cleopatra, por tu regio sepulcro, / si una víbora yace en un túmulo más noble". Marcial, Epigramas, IV, 59.5. Transcripción: MARTIAL, Epigrammata, Wilhelm Heraeus, Jacobus Borovskij, Ed. en Perseus Digital Library: http://www.perseus. tufts.edu/hopper/ (19/10/13). Traducción según MARCIAL. Epigramas. 2 vols. Introducción, traducción y notas de Juan Fernández Valverde y Antonio Ramírez de Verger, Madrid, Gredos, 1997.
} 
Los monarcas macedonios mantuvieron, no obstante, la vinculación con Alejandro Magno que les dotaba de una identidad helenística, y que, además, en Egipto, subrayaba su carácter de salvadores frente a la dominación persa. El sincretismo greco-egipcio se constituyó como un gesto de profundo respeto por la cultura egipcia y desechó las fórmulas de imposición cultural; esta simbiosis resultó tan atinada que Cleopatra VII ha pasado a la historia como la última reina de Egipto y uno de los iconos más importantes de la civilización egipcia, a pesar de su origen heleno.

La labor legitimadora de esta reina, lejos de ser innecesaria por la consolidación de la dinastía fue, no obstante, mucho más laboriosa, pues hubo de asentarse en el interior del territorio, en dura liza con sus hermanos, y también en el exterior de cara a la conservación de la independencia del país, consciente como hubo de ser Cleopatra de la inminente expansión romana. En el interior continuó y reelaboró los sistemas de legitimación dinásticos, subrayando su propia divinización en relación con la diosa Isis, cuyo culto se estaba extendiendo por todo el ámbito Mediterráneo. En Roma, donde más rechazo originó su figura, se esforzó por mostrarse como una reina estrechamente asociada con la divinidad.

Aunque las críticas de los entornos más conservadores de Roma se centraron principalmente en las costumbres de la corte alejandrina, entregada al lujo y los placeres, probablemente, lo más inquietante de la reina a su paso por Roma fue la legitimidad que exhalaba su figura, una legitimidad que se había consolidado a lo largo de años de elaborados programas iconográficos y que presentaba a Cleopatra como una Reina, cuya figura personificaba la dilatada herencia de la cultura egipcia.

Marco Antonio, sorprendido por el rechazo que provocaba su relación, interrogaba a Augusto:

...scribit etiam ad ipsum haec familiariter adhuc necdum plane inimicus aut hostis: 'quid te mutauit? quod reginam ineo?...66

$$
* * * * *
$$

\section{Fuentes}

APIANO, Historia Romana. Vol II. Guerras Civiles (Libros I-III). Traducción y notas de Antonio Sancho Royo, Madrid, Gredos, 1985, 329 p.

DION CASIO, Historia Romana. Libros I-XXV. Introducción, traducción y notas de Domingo Plácido Suárez, Madrid, Gredos, 2004, 668 p.

DiOn CASIO, Historia Romana. Libros XXXVI-XLV. Traducción y notas de José $\mathrm{M}^{\mathrm{a}}$ Candau Morón y Ma Luisa Puertas Castaños, Madrid, Gredos, 2004, 484 p.

\footnotetext{
66 "En una época en que no era aún su enemigo declarado, Antonio le escribía familiarmente: ¿Qué te ha cambiado? ¿Que sea mi amante una reina?...". Suetonio, Los Doce Césares, 'Octavio Augusto', LXIX, 2. Transcripción: C. Suetonius Tranquillus, Divus Augustus. Maximilian Ihm, Ed. en Perseus Digital Library: http://www.perseus.tufts.edu/hopper/ (19/10/13). Traducción según Suetonio, C. Vida de los Doce Césares (2 vols.). Introducción general de Antonio Ramírez de Verger. Traducción de Rosa Ma Agudo Cubas. Madrid, Gredos, 1992.
} 
MARCIAL, Epigramas. 2 vols. Introducción, traducción y notas de Juan Fernández Valverde y Antonio Ramírez de Verger, Madrid, Gredos, 1997, 384 p. (vol. I), 448 p. (vol. II).

Ovidio, Metamorfosis. Edición y traducción de Consuelo Álvarez y Rosa $\mathrm{M}^{\mathrm{a}}$ Iglesias, Madrid, Cátedra, 2009, 824 p.

Plutarco, Isis y Osiris. Traducción de Mario Meunier. Según edición de 1930. Isis y Osiris. (Versión hecha sobre la traducción francesa, con prefacio, prolegómenos y notas de Mario Mecnier por F. Gallach Pales). Barcelona, Obelisco, 2006, 158 p.

PlUTARCO, Vidas paralelas. Demetrio-Antonio. Introducción, traducción y notas de Juan Francisco Martos Montiel. Madrid, Alianza, 2007, 275 p.

SuETONIO, Vida de los Doce Césares (2 vols.). Introducción general de Antonio Ramírez de Verger. Traducción de Rosa $\mathrm{M}^{\mathrm{a}}$ Agudo Cubas, Madrid, Gredos, 1992, 396 p. (vol. I), 376 p. (vol. II)

\section{Bibliografía}

ARroYo, Ma Amparo, «Isis y Serapis: Legitimadores de la realeza en época ptolemaica». En Boletín de la Asociación Española de Egiptología (B.A.E.D.E.), n 9 , año 1999, p. 157-174.

ARroYo, $\mathrm{M}^{\mathrm{a}}$ Amparo, «El Culto Isiaco en el Imperio Romano. Cultos Diarios y Rituales Iniciáticos». En Boletín de la Asociación Española de Egiptología (B.A.E.DE.), no 12, año 2002, p. 207-232.

ARROYO, Ma Amparo, «Aspectos iconográficos de la magia en el antiguo Egipto: Imagen y palabra», Akros. Revista del Museo de Melilla, no 8 (2009), p. 63-72.

BAINES, John y MÁLEK, Jaromir. Atlas of Ancient Egypt, Oxford, Phaidon, 1984, $240 \mathrm{p}$.

BAYET, Jean, La religión romana: historia política y psicológica, París, Cristiandad, 1984, 346 p., 32 lám.

BECKERATH, Jürgen von, Handbuch der Ägyptischen Königsnamen, MunichBerlín, Deutscher Kunstverlag, 1984, 314 p.

Bowman, Alan K., Egypt after the Pharaohs, 332 BC-AD 642: from Alexander to the Arab conquest, Berkeley, Uiversity of California Press, 1986, 268 p.

BRADY, Thomas Allan, Serapis \& Isis. Collected Essays, Chicago, Ares, 1978, 129 p.

CASTEL, Elisa, Egipto. Signos y símbolos de lo sagrado, Madrid, Alderabán, 1999, $437 \mathrm{p}$.

CASTEL, Elisa, Gran Diccionario de Mitología Egipcia, Madrid, Alderabán, 2001, $554 \mathrm{p}$.

CotTEREll, Arthur (coord.), Historia de las Civilizaciones Antiguas. Egipto, Oriente Próximo, Barcelona, Crítica, 1987, $2^{\mathrm{a}}$ ed., 414 p.

De RaChewIltz, Boris y PARTINI, Anna Maria, Roma Egizia. Culti, templi e divinitá egizie nella Roma Imperiale, Roma, Mediterranee, 1999, 257 p.

FRANKFORT, Henri, Reyes y Dioses: Estudio de la religión del Oriente Próximo en la antigüedad en tanto que integración de la sociedad y la naturaleza, Madrid, Revista de Occidente, 1976, 473 p. 
GARDINER, Alan, Egyptian Grammar, Oxford, Univesity Printing House, 1988 (3 ed. revisada), $646 \mathrm{p}$.

GRIMAL, Nicolas, Historia del Antiguo Egipto, Madrid, Akal, 2004, $2^{\mathrm{a}}$ ed, 556 p.

GRIMAL, Pierre, Diccionario de Mitología Griega y Romana, Barcelona, Paidós Ibérica, 1981, $634 \mathrm{p}$.

HERRERO, Carmen, Introducción a la numismática antigua. Grecia y Roma, Madrid, ed. Complutense, 1994, 268 p., XIV lám.

LÓPEZ, Mercedes, «Isis y Sarapis: Difusión de su culto en el mundo grecorromano». En Minerva. Revista de Filología Clásica, no 6, año 1992, p. 161-192.

Lo SARDO, E. (ed.), La Lupa e la Sfinge. Roma e l'Egitto dalla storia al mito. Catálogo de la Exposición. Roma, Museo Nazionale di Casteli Sant'Angelo (11 Iuglio - 9 novembre 2008), Milán, Electa, 2008, 215 p.

Olaguer-Feliú, Fernando de, Alejandro Magno y el Arte. Aproximación a la personalidad de Alejandro Magno y su influencia en el Arte, Madrid, Encuentro, 2000, 189 p.

ONIANS, John, Art and Thought in the Hellenistic Age. The Greek World View. 350 a.C.-50 b.C., Londres, Thames and Hudson, 1979, 192 p.

PlATNER, Samuel Ball y ASHBY, Thomas, A Topographical Dictionary of Ancient Rome, Londres, Oxford University Press, 1929, 608 p. On-line en: http://penelope.uchicago.

edu/Thayer/E/Gazetteer/Places/Europe/Italy/Lazio/Roma/Rome/_Texts/PLATO $\mathrm{P} * /$ home*.html (16/10/13).

RAMOS, Alberto y MATA, Dulce, «Gestación y nacimiento en el Antiguo Egipto», Revista de Obstetricia y Ginecología de Venezuela, v. 62, n. 2, año 2002, p. 141144.

Roullet, Anne, The Egyptian and Egyptianizing Monuments of Imperial Rome, Leiden, E.J. Brill, 1972, 184 p., 230 plates, 3 plans.

SÁNCHEZ, Ángel, Diccionario de Jeroglíficos Egipcios, Madrid, Alderabán, 2000, $605 \mathrm{p}$.

SchulZ, Regine y SEIDEL, Matthias (ed.), Egipto. El mundo de los faraones, Madrid, Könemann, 1997, 538 p.

SHAW, Ian (ed.), Historia del Antiguo Egipto, Madrid, Esfera de los Libros, 2007, $671 \mathrm{p}$.

Siliotti, A., Egipto. Templos, hombres y dioses, Barcelona, Óptima, 2001, 290 p.

TRAN TAM TINH, Vincent, Le Culte des divinités orientales en Campanie en dehors de Pompéi, de Stabies et d'Herculanum, Leiden, E.J. Brill, 1972, 261 p., 73 lám.

Trigger, Bruce G., KeMP, Barry J., O’Connor, David B. y Lloyd, Alan B., Ancient Egypt. A Social History, Cambridge, Cambridge University Press, 2001, $450 \mathrm{p}$.

VV.AA., The Treasures of the Egyptian Museum, El Cairo, The American University in Cairo Press, 1999, 416 p.

WALKER, Susan y Higgs, Peter (ed.), Cleopatra of Egypt: from history to myth. Catálogo de la Exposición, Londres, The British Museum Press, 2001, 384 p.

WALTERS, Elizabeth J., Attic grave reliefs that represent women in the dress of Isis, Princenton - Nueva Yersey, American School of Classical Studies at Athens, 1988, 134 p., 52 lám. 